\title{
EMPLOYER LEARNING AND THE DYNAMICS OF RETURNS TO UNIVERSITIES: EVIDENCE FROM CHINESE ELITE EDUCATION DURING UNIVERSITY EXPANSION
}

\author{
Sylvie Démurger \\ Eric A. Hanushek \\ Lei Zhang \\ Working Paper 25955 \\ http://www.nber.org/papers/w25955 \\ NATIONAL BUREAU OF ECONOMIC RESEARCH \\ 1050 Massachusetts Avenue \\ Cambridge, MA 02138 \\ June 2019, Revised March 2023
}

We thank Jerome Adda, Yuan Jiang, Mark Rosenzweig, Michael Waldman, Jing Zhang, Junsen Zhang, and two anonymous referees for helpful comments and discussions. Lei Zhang acknowledges financial support from the National Natural Science Foundation of China (grant number 71973095). The views expressed herein are those of the authors and do not necessarily reflect the views of the National Bureau of Economic Research.

NBER working papers are circulated for discussion and comment purposes. They have not been peer-reviewed or been subject to the review by the NBER Board of Directors that accompanies official NBER publications.

(C) 2019 by Sylvie Démurger, Eric A. Hanushek, and Lei Zhang. All rights reserved. Short sections of text, not to exceed two paragraphs, may be quoted without explicit permission provided that full credit, including $(\odot$ notice, is given to the source. 
Employer Learning and the Dynamics of Returns to Universities: Evidence from Chinese

Elite Education during University Expansion

Sylvie Démurger, Eric A. Hanushek, and Lei Zhang

NBER Working Paper No. 25955

June 2019, Revised March 2023

JEL No. I20,I23,J2

\section{ABSTRACT}

This paper estimates the return to an elite university education over a college graduate's career in contemporary China. We find a substantial premium for graduating from an elite Chinese university at the job entry that declines quickly in early career before starting to return subsequently. This pattern holds after allowing for university selectivity by including individual admission scores. It is entirely driven by the post-expansion cohorts who entered college after the higher education expansion that started in 1999. The pattern is more pronounced in coastal provinces and in economically more developed regions, where individual skills are highly rewarded in the labor market. The results are consistent with predictions of asymmetric employer learning models, both at the job entry and at the mid-career when individuals are up for promotions.

Sylvie Démurger

Department of Economics

ENS de Lyon - CNRS

15 parvis René Descartes

69007 Lyon

France

sylvie.demurger@cnrs.fr

Eric A. Hanushek

Hoover Institution

Stanford University

Stanford, CA 94305-6010

and NBER

hanushek@stanford.edu
Lei Zhang

Antai College of Economics

and Management

Shanghai Jiao Tong University

1954 Huashan Road

Shanghai, 200030

P. R. China

zlei89@gmail.com 


\section{Introduction}

While no one doubts that colleges and universities differ in quality, often defined by selectivity in student admissions and by the quality of the faculty research, there is less understanding of the implications of any quality differentials for student outcomes. For a variety of reasons, investigating differential returns to college quality proves to be a difficult research question. A particularly attractive laboratory for studying the college quality-student outcome nexus is contemporary China that combines a dramatic expansion of universities with both a recognized identification of elite universities and a responsive labor market. Investigation of the impact of China's elite universities provides insights not only about the operation of its dynamic labor market but also about the role of employer learning in determining labor market outcomes.

Three central problems in understanding the labor market outcomes of universities have plagued prior research. First, it has been difficult to separate the impact of the university from the selection of students into them, especially given a common assessment of college quality based on the incoming quality of students. Second, the difficulty of obtaining career information for a representative sample of graduates from different universities has frequently limited the scope and generalizability of previous analyses. Third, changing overall college attendance rates that alter the labor market for college graduates over time complicate understanding the evolving labor market aspects of higher education. While not immune from these challenges, this research addresses each.

Our analysis straddles two separate lines of research. One line of research focuses on differential college quality - where quality is generally identified by some external judgment about quality or by some proxy such as selectivity of admissions or expenditures. The validation of the various quality measures then comes from estimating differential college impacts on student labor market outcomes, thus introducing the challenge of finding ways to separate exogenous student skills from the quality of the school. The second line of research, while generally not addressing school quality per se, directly considers labor market aspects of employer uncertainty about applicant skills during the hiring phase. Depending on the information that they have, employers may make initial hiring decisions based on error-prone suppositions of individual skills but then adjust these judgments after workers have been on the job.

These two lines of research come together when proxies for college quality are used by employers as indicators of individual skills at the hiring point. Specifically, the investigations of college quality, which often use just early career labor market outcomes, could reflect initial employer decisions that differ from a more complete picture of labor market returns that incorporate subsequent employer learning. 
Our primary objective is evaluation of the economic return to attending elite Chinese universities, which requires a broad investigation of the dynamics of the college quality wage premium. Much of the attention to the Chinese economy has focused on the huge shifts of industries with substantial changes in technologies. In the background, however, the labor market in China has undergone a tremendous transformation following the massive expansion of higher education since the late 1990s (Knight, Deng, and Li (2017)). The surge in the supply of the college-educated labor force clearly alters the dynamics of returns to college quality both over individual careers and across age cohorts. Thus, we look both at how the premium changes with an individual's labor market experience (the experience profile) and at how it varies over time for different cohorts (the intertemporal profile).

This paper employs particularly rich data about labor market performance of graduates from different colleges and at different times in order to investigate the returns to worker skills. We use the 2013 urban sample from the China Household Income Project (CHIP) survey to construct work histories for a panel of fulltime workers. Importantly, this data set also includes scores on the precollege admission test (Gaokao), which allows us to separate the impact of elite colleges from their selection on individual skills at admission. From these work histories, we estimate how the premium for graduating from an elite college evolves over the working career and investigate variations in the returns to elite colleges across time, occupations, and market conditions.

We find a significant premium at job entry for graduating from an elite university, but this premium declines quickly in the first few years on the job and then rises again in a subsequent career phase. These dynamics are entirely driven by the recent cohorts of students entering college since higher education expansion, suggesting an increasing importance of college quality with the surge in college graduates. This pattern is most pronounced in economically more developed regions.

The dynamic pattern of the elite-college premia with employer learning remains the same when college selection through the Gaokao admission tests is considered. Interestingly, the impact of the selection into elite universities as measured by the Gaokao score remains constant across the career, suggesting that employers are able to observe the relevant skills through other information at hiring.

The findings about the initial premium and the rapid employer learning are remarkably stable across industries and occupations and across a variety of sensitivity checks including allowing for city-specific time trends in wages and for individual fixed effects. They are, however, more prominent in economically competitive regions.

This article makes several contributions to the existing literature. First, it traces the pattern of returns to college quality in the world's largest labor market during a period of dramatic changes both in the structure of industry and with expansion in access to higher education. Second, unlike other 
analyses that are restricted to early career labor market data, it provides direct information on the longer term impacts of graduation from an elite college given employer learning about skills. Third, it shows how retrospective career information can be employed to provide information about labor market dynamics.

After reviewing related research in the next section, we describe the underlying conceptual framework and the data base in Section 3. The empirical results in Section 4 include a series of specification analyses and robustness checks, and considers how the varying economic competitiveness of the different provinces affects the labor market outcomes. Conclusions are presented in Section 5.

\section{Related Research}

Estimation of the average returns to selective colleges is heavily weighted toward U.S. experiences and is generally focused on early career impacts. The early work emphasized varying proxies for college quality (e.g., Black and Smith (2004, (2006), Zhang (2009), and Hoekstra (2009)) and generally found significant wage premia associated with attending an elite U.S. university, although this was not uniformly the case (e.g., Dale and Krueger (2002, (2014)). Recent studies have relied on more restricted samples but have focused more on using policy changes to deal with sample selection and to identify the labor market impact of college quality (e.g., Cohodes and Goodman (2014), Bleemer (2021), Black, Denning, and Rothstein (2023)). ${ }^{1}$ They find generally positive impacts of selective colleges.

Internationally, Broecke (2012) and Anelli (2020) find similar results for the UK and Italy, respectively. For Chile, Hastings, Neilson, and Zimmerman (2014) and Zimmerman (2019), using regression discontinuity methods, find significant labor market returns to selective colleges. ${ }^{2}$ BarreraOsorio and Bayona-Rodríguez (2019) and MacLeod, Riehl, Saavedra, and Urquiola (2017), using different methodologies with data from Colombia, rely on the newly developed program exit exams to identify the source of wage premia for elite college graduates. Both find a reputational premium to elite colleges that they interpret indicating signaling, while MacLeod, Riehl, Saavedra, and Urquiola (2017) also point to productive elements of universities. ${ }^{3}$

\footnotetext{
${ }^{1}$ See the broader review of prior studies in Black, Denning, and Rothstein (2023).

${ }^{2}$ Beyond the wage impacts, using Chilean data, Kaufmann, Messner, and Solis (2015) find significant positive impacts on the marital outcome of women attending an elite university and on the academic performance of children whose parents attend an elite university.

${ }^{3}$ Neither provides any direct evidence of the reliability or validity of the program exit exams. The BarreraOsorio and Bayona-Rodríguez (2019) conclusions rest on the lack of correlation of entry and exit examination scores, suggesting that there is no value-added of colleges to skills. But this also leads to questions about the
} 
Studies for China are quite limited. Li, Meng, Shi, and Wu (2012) and Jia and Li (2021) using data from wage offers to college students just prior to graduation, show that graduates of elite universities in 2010-2015 experience a sizable wage premium at labor force entry. Kang, Peng, and Zhu (2021), using data from the 2014 China Family Panel Studies (CFPS), demonstrate that wage patterns for graduates differ by subject studied and by college quality tier. ${ }^{4}$

Across prior studies, a central focus has been dealing with the student selection into different universities in order to understand the labor market impact of university quality. While a variety of analytical approaches and specialized samples have been used to address selection, most studies have been forced to look at early career impacts. But, as we discuss below, the initial impacts of university quality may be very different from the longer term impacts seen across the career.

The parallel literature on firm hiring and employer learning focuses on how firms dynamically adjust to error-prone information about worker skills. This line of research is relevant for understanding college quality premia if employers rely on ratings of colleges such as prestige rankings or measures of selectivity of admissions to judge applicants for jobs. Initial wage premia for graduates of selective schools may change significantly as employers learn about individual performance, making the lifetime impacts of selective colleges potentially different from the immediate impacts.

In the employer learning models of Farber and Gibbons (1996) and Altonji and Pierret (2001), employers have limited information about workers' productivity at entry into the labor market. Employers use readily observable characteristics such as the education level that are believed to be correlated with productivity for initial hiring and wage decisions, but they rely less on such proxies for setting wages as they accumulate more information about workers' true productivity. Testing this theory with U.S. data, both studies find that the returns to cognitive skills (initially unobserved to the employer) increase over the worker's career. Altonji and Pierret (2001) additionally find that the return to each year of education (readily observed initially) decreases over the worker's career.

Arcidiacono, Bayer, and Hizmo (2010), however, suggest that U.S. employers get sufficient individual information from college applicants but that the general learning model holds for high school graduates. Mansour (2012) finds that employer learning about worker skills differs substantially by occupation. More recently, Castex and Dechter (2014) find higher returns over time

exit examination itself. MacLeod, Riehl, Saavedra, and Urquiola (2017) show that employers reduce their reliance on college reputation when the exit exams are available but do not address returns to the exit exam itself.

${ }^{4}$ Zhong (2011), using data from the 2002 China Household Income Project (CHIP), finds that wages vary by the subjective rankings of colleges and universities but returns are not monotonically related to the five quality categories (from poor to very good) obtained from individual survey responses. 
to educational attainment and lower returns to cognitive skills in the U.S., a pattern they attribute to slower technological growth in recent periods.

A few international papers have also documented that college prestige serves as an entry signal that becomes less important throughout workers' careers (Lang and Siniver (2011) for Israel; Bordón and Braga (2020) for Chile; Araki, Kawaguchi, and Onozuka (2016) for Japan). The case of Colombia is interesting because the introduction of course-specific exit examinations - which job applicants apparently put on their resumes - implies much less uncertainty about individual skills if the examinations are reliable (Barrera-Osorio and Bayona-Rodríguez (2019); MacLeod, Riehl, Saavedra, and Urquiola (2017)).

These learning models assume symmetric learning such that current and prospective employers learn about individual productivity equally well over time, and hence education only has a signaling value at labor market entry. A recent strand of literature, however, emphasizes asymmetric learning after labor market entry. If current employers have more information about a worker's ability than the general labor market, education may play a signaling role later in the career through, for example, subsequent promotions and associated wage premia (Bernhardt (1995); Schönberg (2007); DeVaro and Waldman (2012); Waldman (2016)). ${ }^{5}$

These separate lines of research together point to the importance of dynamic considerations in the estimation of the labor market impact of elite colleges. Our analytical approach is motivated by this prior work indicating that employers take quality signals from the prestige of the college but that they subsequently update these estimates of worker skills based on performance. The rich nature of the Chinese labor market experience with its rapidly evolving labor market and with a dramatically changing schooling system, however, indicates that the application of these ideas must incorporate the distinctive features of the Chinese economy.

\footnotetext{
${ }^{5}$ The gist of the asymmetric learning and the signaling value of education in promotion is that a worker's current employer learns privately about the worker's abilities, whereas prospective employers try to infer information about the worker by observing the actions of the current employer. A promotion signals higher ability, and prospective employers will bid more for a promoted worker, which prompts the current employer to offer a large wage raise to this worker. Thus, firms generally promote to less than the efficient level to avoid paying the wage premium associated with promotions. More highly educated workers are favored in the promotion process because the wage premium due to the promotion signal is smaller for such workers (Waldman (2016)).
} 


\section{Data and Analytical Structure}

Our analysis employs particularly rich data that link individual labor market outcomes to their schooling and background characteristics. The empirical models focus on dynamic aspects of the value of attending an elite college in China during a time of rapid change in both the economy and the skills of workers.

\subsection{The Chinese Context}

China's unprecedented higher education expansion began in $1999 .{ }^{6}$ Nationwide, as shown in the top panel of Figure 1, college admissions increased by over 40 percent in both 1999 and 2000 and then continued to grow at more than 10 percent per year through 2005. Because dropout rates are extremely low in the Chinese higher education system, ${ }^{7}$ the sharp expansion in admissions translated into large increases in the number of 4-year college graduates, starting in 2003 (see the lower panel of Figure 1). The number of 4-year college graduates doubled between 1999 and 2003 and quadrupled by 2007.

There are two broad categories of universities in China: elite universities and ordinary universities. Elite universities are defined as the Project-211 universities designated in 1995 by the Ministry of Education (MOE) of China. ${ }^{8}$ These Tier-1 universities are directly under the administration of the MOE and comprise 116 out of the more than 2,000 institutions of higher education in China in 2006. Other universities (ordinary universities) are administered by the Education Department of the province in which they are located. The MOE decides on the number of students that may be admitted to each elite university in each year, whereas the Education Department in each province decides on that of ordinary universities in the respective province.

To gain admissions to any university, high school graduates take the nationwide college entrance exam (Gaokao) in early summer each year, and their potential eligibility for college admissions is largely determined by the Gaokao score. Elite universities are highly selective and, with some exceptions, just admit applicants with a Gaokao score above a high threshold. Individuals with Gaokao scores above a lower threshold are eligible for ordinary universities, and those with

\footnotetext{
${ }^{6}$ See Che and Zhang (2018) for a detailed description of the reform of the higher education system.

${ }^{7}$ As reported in Jia and Li (2021), China's college system is based on high entry requirements and known for having among the lowest dropout rates in the world, although no systematic data on graduation rates are readily available for individual universities in China.

${ }^{8}$ See https://en.wikipedia.org/wiki/Project_211 [accessed January 17, 2023]
} 
scores above a minimum cut-off may be admitted to a 3-year college. ${ }^{9}$ Given the excess demand for admission to elite schools and the nature of the admission process, however, many students above the Gaokao admission thresholds do not apply or are not admitted and instead go to lower ranked schools, leading to a large overlap in the distribution of Gaokao scores at elite and ordinary universities (Jia and Li (2021)).

Figure 2 displays the changing distribution of admissions by college types, something that is particularly relevant for the analysis here. ${ }^{10}$ The logarithmic plot shows clearly the much larger growth in 3- and 4-year colleges compared to the elite colleges. ${ }^{11}$ The vast majority of increased college admissions is found in ordinary 4-year and 3-year colleges, which jumped in absolute terms from less than 750,000 new students in 1998 to 4.5 million in 2006. At the same time, admissions to elite 4-year universities remained virtually unchanged after 2000, increasing by at most a few thousand each year to reach just over 400,000 in 2006. The difference in admissions growth translates into a growing proportion of graduates from ordinary universities.

Elite universities receive substantially more funding and are able to hire higher-quality faculty than ordinary universities, and the resource gap has been growing over time. As one simple measure, the gap between elite universities and ordinary universities in the average share of faculty holding a $\mathrm{PhD}$ degree soared from 8 percentage points in 1998 to 22 percentage points in 2006 (see Figure 3). ${ }^{12}$

As a consequence of changes in both the relative selectivity of the elite sector and its relative resource advantages, we may expect a larger role played over time by the college tier in signaling the

\footnotetext{
${ }^{9}$ Since the mid-2000s, an increasing number of Chinese high school graduates have started to go to college overseas. No systematic statistics are available for the scale and destinations of this group. Based on information from the U.S. Department of Homeland Security (https://studyinthestates.dhs.gov/sevis-datamapping-tool) and surveys by Yi Xiao, a Chinese data analysis company (http://www.myfitcollege.com/), we calculate that the number of students starting at a 4-year college abroad increases from $1.4 \%$ in 2014 to $1.6 \%$ in 2019 relative to those starting a 4-year college education within China. They are distributed in a wide range of countries and institutions, although half attend in the U.S.. It is highly plausible that this group is much smaller for the cohorts studied here and unlikely to affect the relative selectivity of the elite and ordinary universities.

${ }^{10}$ Due to limited access, we have data only for the period of 1998 to 2006.

${ }^{11}$ Note that Table 1 below shows considerably less divergence of ordinary and elite admissions. This reflects the differences in sampling behind the data. The CHIP survey covers only urban residents, with an urban Hukou. Elite college graduates are more likely to come from urban areas and stay and work in the urban areas than ordinary college graduates post of the expansion, and hence to be over-sampled by CHIP.

${ }^{12}$ Elite and non-elite universities may also differ in terms of the bachelor programs they provide, which may lead to different occupations with different labor market returns. It may be the case for instance if elite universities have higher technology-based majors while newer, ordinary universities choose to provide majors that are less costly. We are not aware of any readily available data regarding potential differences in bachelor programs offered across university types that would allow us to explore this further. Nevertheless, we can address this issue in our empirical work by using occupation fixed effects, and we show below that our results hold within occupation.
} 
ability of college graduates at job entry with potentially larger adjustments as employers learn about individual productivity. This changing component of the evolution in returns is what we call the "intertemporal profile" of the college quality premium.

Our analysis focuses on the equilibrium wage outcomes of elite college graduates. The labor market dynamics of course depend not only on the supply of varying quality graduates but also on the demand for them. As is well-known, the Chinese economy has changed dramatically over the past few decades leading to considerable heterogeneity in demand both by sectors and by geographical regions. These dynamics may be more salient for individuals working in the private sector or in regions that experience more marketization than for those working in the public sector or in less market-oriented regions.

\subsection{China Household Income Project (CHIP) Survey Data}

The 2013 China Household Income Project (CHIP) survey provides high quality data on employment and background for a representative sample of the Chinese urban population from 14 provinces. ${ }^{13}$ It contains detailed information on individual characteristics including gender, age, education attainment, quality tier of college, year, province, subject of study, and the Gaokao score. The labor market information includes current salary, working hours, industry, sector, occupation, and starting year and salary at the current job.

Importantly, the job history information allows us to construct labor market histories with current and starting monthly wages for the 2013 job. For each individual, we thus have two observations in time that we use to build a panel database. Monthly wage in 2013 is annual income divided by months worked during 2013, and the survey reports directly monthly salary at the start of the current job. ${ }^{14}$ All monetary values are CPI-adjusted to be measured in constant 2013 Yuan. ${ }^{15}$

Our primary sample includes all four-year college graduates who are working full-time (at least 6 hours per day and 20 days per month). ${ }^{16}$ We define our post-expansion cohort as individuals

\footnotetext{
${ }^{13}$ The 14 provinces include coastal, central, and western provinces at different stages of development, and they are sampled to represent the overall economic development of China.

${ }^{14}$ Using hourly wage in the empirical analysis yields similar results.

${ }^{15}$ Regional and time price variations are accounted for by adjusting all monetary values for provincial purchasing power differences, calculated from the urban provincial-level spatial price deflators computed by Brandt and Holz (2006), and updated to 2013.

${ }^{16}$ Full-time work is widespread among college graduates, with 98.7 percent of them in our sample working full time. Yet, since non full-time work is more prevalent among ordinary university graduates, we checked the robustness of our results by running all the estimations for the sample of both full-time and part-time workers. None of the empirical findings change. These estimates are available upon request.
} 
born in 1980 or later. They were admitted to college after the start of the higher education expansion in 1999 and entered the labor market along with a substantially larger number of college graduates. ${ }^{17}$

The 2013 CHIP survey elicits self-reported information on each individual's university type and college entrance exam (Gaokao) score. The raw Gaokao scores differ by year-province-subject (sciences v. humanities) and are not directly comparable. ${ }^{18}$ We normalize them in two steps. First, because the maximum possible score varies with the specific test, we divide individual scores by the maximum possible score of each specific test. ${ }^{19}$ We assume that the population distributions are comparable over time and across provinces and subjects, which allows us to convert this percentage score into a z-score with a mean of zero and a standard deviation of one. The normalization is performed for the entire sample of individuals reporting the Gaokao score regardless of their current working status. While the assumption of a common mean score across provinces is strong and untested, it is unlikely to affect our empirical results. All of our estimates below include city fixed effects so that the comparisons are restricted to within-city comparisons.

The distribution by educational attainment of fulltime workers in the 2013 CHIP sample is shown in Table 1. Although we are focused on college graduates, we report statistics for all full-time workers to highlight the trend in increasing education attainment. Consistent with our subsequent analysis, we divide the population into pre-expansion workers (born up to 1979) and post-expansion workers (born after 1979).

As seen in Panel A, educational attainment in China has increased significantly: full-time workers with less than a high school education in the post-expansion cohort are about half that of the pre-expansion cohort (16.5 percent v 35.1 percent). With the higher education expansion from 1999 onwards, 33 percent of the post-expansion cohort has at least a 4-year college degree, an 80 percent increase over the pre-expansion cohort. While fewer females of the pre-expansion cohort are college-

\footnotetext{
${ }^{17}$ The pre-expansion cohort is individuals born between 1953 and 1979. Results are not sensitive to using 1981 as the cut-off year for defining cohorts.

${ }^{18}$ The college entrance exams are based on a national education curriculum. With the approval of the MOE, a province may choose to write its own tests, which may have different maximum possible scores from the national tests and from tests of other provinces.

${ }^{19}$ For example, the maximum possible score was 640 for the humanity-oriented test and 710 for the scienceoriented test in 1989 for all provinces. It was changed to 750 in 1994 for both tests nationwide. Starting in 1999, several provinces, such as Fujian, Guangdong, Shaanxi, and Hainan adopted different tests with a maximum possible score of 900 for both tests. There are larger cross-province variations in more recent years as more provinces started to experiment different test regimes. The maximum possible score is obtained from various Gaokao-related websites such as http://edu.sina.com.cn/Gaokao/. It is missing for a small number of years and provinces, and individual observations are therefore dropped for these years and provinces.
} 
educated, females of the post-expansion cohort surpass males by more than 6 percentage points. Nevertheless, relatively fewer females graduate from an elite university.

Panel B reports public sector employment shares by education level. ${ }^{20}$ Except perhaps at the lowest education levels, public employment drops across the education distribution, consistent with the growth of the private sector over the past 20 years. Similar patterns hold if employment in stateowned enterprises (SOEs) is excluded (col. 4-6), assuming SOEs are also subject to similar, albeit lesser, market forces than purely private firms. Post-expansion elite university graduates are relatively more likely than other university graduates to enter public service or other governmental institutions, thus being more protected from private market forces (and, as we show below, receiving a continuing wage premium).

Figure 4 plots the density of the Gaokao z-score by cohort and college quality tier. Two things are interesting about these distributions. First, while the means differ across the two college sectors, there is considerable score overlap between the elite and the ordinary universities. Knowing somebody graduated from an elite university implies a higher average score but does not mean the person is necessarily at the top of the overall ability distribution. Second, on average there is a significantly larger disparity in the Gaokao score between graduates of the elite and ordinary universities for the post-expansion cohort; the means are 0.89 (elite) and 0.29 (ordinary) for the postexpansion cohort but 0.74 and 0.41 for the pre-expansion cohort. These distributional patterns indicate changing selectivity on the basis of cognitive skills that employers are likely to observe. ${ }^{21}$

The difference in information about graduates before and after expansion motivates our separate estimates of the elite wage premium for the two periods. It is also consistent with the popular discussions. With college expansion, two types of stories become more and more prevalent on the news media. On one side, it is the stories about how difficult it is for college graduates to find a job. On the other side, stories abound about the privileges elite university graduates enjoy in both job search and in their starting salary. For example, coveted employers only conduct campus recruiting in elite (211/985) universities. ${ }^{22}$ Some job advertisements explicit state entry-level salaries for graduates from different types of universities. In one example of a SOE, almost all of the applicants of elite

\footnotetext{
${ }^{20}$ Public sector includes government agencies, all public schools/universities, hospitals, other public institutions, and state-owned enterprises (SOEs); private sector includes all other employers, i.e., firms and non-farm small businesses of all ownerships except for SOEs.

${ }^{21}$ A high Gaokao score is, however, not the only way to be admitted to an elite university. There exist exemptions in the eligibility of admissions to elite universities, due to ethnic minority status, being athletes, having talents in arts, being children of parents who died for the country, etc. These students are admitted even if they have very low Gaokao score.

${ }^{22}$ There are many anecdotes posted on the internet, for example, https://www.qlrc.com/news/52944.html; https://www.zhihu.com/question/441088921/answer/1813517945; https://www.zhihu.com/question/441088921.
} 
universities were hired, whereas only the most competitive ones from ordinary universities were hired. Graduates recruited from elite universities received between more than $10 \%$ and more than $20 \%$ higher salary at job entry than those from ordinary universities. ${ }^{23}$ Moreover, most of the stories are about experiences of job search and outcomes when college graduates first enter the labor markets. Later career experiences are rarely discussed, perhaps because later experiences are more individual-specific.

\subsection{Empirical Models}

The focus of our empirical model is how the wages of college graduates attending an elite university evolve over their careers relative to their peers attending an ordinary university. We start by replicating the basic analysis of average returns to graduates from an elite institution, paralleling the most common approach in the literature, and then move to the dynamics.

\section{Average Returns to University Quality}

The canonical approach for identifying the average returns to college quality is estimation of an augmented Mincer equation such as:

$$
\ln \left(\text { wage }_{j}\right)=\alpha+\gamma_{1} P E_{j}+\gamma_{2} P E_{j}^{2}+\delta X_{j}+\theta \bullet \text { elite }_{j}+\varepsilon_{j}
$$

In this simplest form (Eq. 1), $\ln \left(\right.$ wage $_{j}$ ) is the natural logarithm of monthly wage of individual j; $P E$ (=age-years of schooling-6) is years of potential experience in the labor market; $X$ is a vector of control variables; elite is an indicator equal to 1 for a graduate of an elite university and 0 otherwise; and $\varepsilon$ is a stochastic error term. ${ }^{24}$

In this estimation, $\theta$ gives the average returns to attending an elite university, something that will incorporate both the impact of elite colleges and selection into the colleges. For Chinese college graduates, the quality tier of their college constitutes a widely-used and observable proxy for labor market skills. Graduates of elite universities are deemed either to have higher innate ability (signaling model) or to have acquired more human capital in the richer learning environment of the elite universities (human capital model). Which of the two mechanisms (the selection of individuals with high cognitive skills versus the production of skills by schools) is behind the higher skills of elite college graduates is not identified from simple labor market data.

\footnotetext{
${ }^{23}$ https://www.zhihu.com/question/441088921/answer/1708127897.

${ }^{24}$ elite might also be an alternative measure of quality such as the average SAT score of admitted students, and it could be composed of multiple measures; see Black and Smith (2006).
} 
This suggests a more sophisticated version where a measure of individual college entry (Gaokao) scores, $G_{j}$, is added to Eq. 1 in order to purge $\theta$ of the selection into the elite schools and to emphasize the value-added of the elite college. ${ }^{25}$ This production function interpretation, of course, depends on how well the Gaokao score represents the relevant inputs into college production.

\section{Dynamic Returns to University Quality}

The prior analysis of employer learning models suggests caution in interpreting this earnings model even in the augmented form with the Gaokao. With the early-career labor market experiences that are generally observed in these college quality estimates, heavy weight is placed on the initial hiring decisions of firms. There is considerable uncertainty about the skills and match quality of young (inexperienced) applicants with a firm, and the firm makes decisions on observed characteristics that are presumed to be correlated with true, underlying skills. After the person is employed, the firm can refine its estimates of the worker's skills and move to better job placement and pay of the individual. As a result, estimates of $\theta$ in early employment may not reflect either the continuing wage premium or the value-added of the elite college. ${ }^{26}$

To estimate the dynamics of the college tier premium, we modify the augmented Eq. 1:

$$
\ln \left(\text { wage }_{j}\right)=\alpha+\gamma_{1} P E_{j}+\gamma_{2} P E_{j}^{2}+\delta X_{j}+\phi G_{j}+f_{P E}\left(\text { elite }_{j}\right)+\varepsilon_{j}
$$

We allow the impact of elite schools to change over the career, $f_{P E}\left(\right.$ elite $\left._{j}\right)$, and we add the college entry score, $G_{j}$.

We start with a convenient characterization of the experience profile for the premium for elite university graduation. We model the time path of the premium as a quadratic function in potential experience as in Eq. 3.

$$
f_{P E}\left(\text { elite }_{i}\right)=\beta_{0} \text { elite }_{j}+\beta_{1}\left(\text { elite }_{j} \times P E_{j}\right)+\beta_{2}\left(\text { elite }_{j} \times P E_{j}^{2}\right)
$$

\footnotetext{
${ }^{25}$ Identification of the screening function of schools is a central element of both Barrera-Osorio and BayonaRodríguez (2019) and MacLeod, Riehl, Saavedra, and Urquiola (2017). Each employs a combination of college entry exam scores and program exit exam scores to address the informational sources of reputational hiring decisions by employers. A key element of these analyses is the validity and reliability of the program exit examinations, a subject that neither addresses.

${ }^{26}$ Note that these interpretative issues are found in the more recent policy impact estimation that rely on early career information; see Daugherty, Martorell, and McFarlin (2014), Bleemer (2021), Black, Denning, and Rothstein (2023). These recent estimates also ignore the dynamics of employer decisions.
} 
$\beta_{0}$ measures the elite premium at job entry; $\beta_{1}$ and $\beta_{2}$ reflect how this premium varies over one's career and are our estimates of the experience profile reflecting employer learning about individual productivity. This specification generalizes the linear model used by Altonji and Pierret (2001), Lang and Siniver (2011), and others. If the labor market is characterized by symmetric employer learning with a strong signaling value of an elite education, we expect $f_{P E}\left(\right.$ elite $\left._{j}\right)$ to decline monotonically. ${ }^{27}$ If, however, learning is asymmetric and an elite education has signaling value later in the career, for example due to higher probability of promotion and the accompanied large wage raise, we expect $\beta_{2}$ to be non-zero and likely positive. We also estimate Eq. 2 using other functional forms for $f_{P E}\left(\right.$ elite $\left._{j}\right)$; in particular, we estimate the experience profile of the premium more flexibly with a stepwise function for years of potential experience.

We include the Gaokao score, $G_{j}$, to address the selection into elite schools and thus to obtain estimates of the labor market impact of attending an elite school, but the cognitive skills measured by these tests may also be directly valued by employers. Two issues thus arise: to what extent does $G_{j}$ measure skills valued by the employer and to what extent are these skills observed by the employer. While job applicants do not typically put Gaokao scores on their resume (partly because of inconsistencies across provinces and time), they do typically provide considerable other information that would allow employers to make inferences about the relevant skills, such as courses taken, GPA, English proficiency, and internship experiences. In the empirical analysis we also consider the possibility of employer learning about the skills measured by the Gaokao, but, similar to the uncertainty about impact in the U.S. literature, we do not have strong priors about either the importance or the dynamic impact of Gaokao scores. ${ }^{28}$

We use the survey information to construct retrospective work histories for all individuals. This provides observations for the starting year of employment with the current firm along with employment information for 2013, the current year. This allows us to track the dynamics of wages for workers across different phases of the education and economic development of China. The use of recall data for starting salary may introduce measurement error, which is possibly larger for the older cohort. While we cannot test it, we believe recall error is likely less problematic here because people might be expected to remember the first salary at the job entry (or the first salary after a job change)

\footnotetext{
${ }^{27}$ In our quadratic formulation of Eq. 3 , this would be consistent with $\beta_{1}$ being negative and $\beta_{2}$ being small or zero.

${ }^{28}$ The U.S. literature has tended to interpret AFQT scores and other cognitive skill measures as true productivity that enter into employer learning. But there is disagreement about whether, particularly for college graduates, employers can infer the requisite skills; see Altonji and Pierret (2001) and Arcidiacono, Bayer, and Hizmo (2010).
} 
more accurately than other intermediate changes in earnings. Differential measurement error may nonetheless contribute to the different results for employer learning across age cohorts.

The main challenge in interpreting the experience profile estimated from Eq. 2 is the potential contamination from secular changes in the returns to an elite university education. Since calendar time is positively correlated with experience, people with longer experience are generally older and have entered the labor market in earlier years. In a simple regression without controlling for secular changes, $\beta_{1}$ and $\beta_{2}$ may reflect the exogenous changes in the return to an elite university education over time in addition to any change in the return over a worker's career from employer learning.

Several specific concerns about secular changes in the Chinese labor market must be dealt with. First, with the growth of the Chinese economy and the increasing adoption of skill-biased technologies, the overall returns to the greater skills of elite university graduates may be larger in recent years due to increased demand for highly skilled workers. As a result, an estimated decline in returns to an elite university education by individual experience may be capturing the lower relative demand for skills in earlier years. This is a particular concern when comparing returns between the pre- and post-expansion cohorts. ${ }^{29}$ Second, as discussed above, the dramatic expansion of college graduates after 1999 could clearly alter the overall labor market for graduates. ${ }^{30}$ Third, China is a large and heterogeneous country, where both industry and university concentrations can follow significantly different time patterns across cities and provinces. ${ }^{31}$

To deal with these facets of the labor market, we incorporate an estimate of exogenous labor market conditions that directly affects educational demand in each province and year. The measure of labor market conditions we construct is generated by the expansion of college workers over time and by the varying relative demand for education levels across industries. We also separately estimate the wage model for pre- and post-expansion cohorts.

Chinese economic policies over the relevant period provide the basis for constructing an exogenous measure of labor market conditions affecting educated workers. China's industrial development, at both national and regional levels, has been strongly shaped by the continued

\footnotetext{
${ }^{29}$ For a discussion of changing returns over time in China, see Liu (1998) and Zhang, Zhao, Park, and Song (2005).

${ }^{30}$ While the expansion of college graduates shows up as a supply shift in human capital, Feng and Xia (2022) show that firms changed their production processes by making deeper capital investments so as to use this new supply. These competing changes are a dramatic version of the race between education and technology highlighted by Goldin and Katz (2008).

${ }^{31}$ Of lesser importance, wages of workers who started working during the years of the planned economy saw compressed wage structures, which could interact with career wage patterns for older workers. Our preexpansion sample, however, includes less than 20 percent of workers who entered their job during that period.
} 
implementation of industrial policies during the entire economic reform period. ${ }^{32}$ These policies allow the government to maintain strong control in resource allocation through administrative approvals (Aghion et al. (2015), Heilmann and Shih (2013), Jiang and Li (2018), Wu (2018)). Specifically, since 1989, the State Council has regularly issued and updated general guidelines and detailed catalogues specifying industries, products, production scales, and production processes that are encouraged, restricted, or marked to be eliminated. The encouraged industries receive fast-track project approvals, land appropriations, bank loans, tax subsidies, and price subsidies in electricity, transportation, and raw materials. The resulting production organization determines to a large extent technologies that are adopted and hence employment composition in each industry at a given period. ${ }^{33}$

The central government's guidelines help shape regional industrial structure primarily in two ways. First, the emphasis on production scale and agglomeration implies that large, incumbent firms are favored and new firms face high entry barriers. Thus, provinces that already have large firms in encouraged industries have greater advantages in expanding further, and vice versa. Second, the guidelines also stipulate regional industrial development priorities. For example, provinces in the central region have been encouraged to develop modern agricultural production and natural resourceintensive manufacturing industries in accordance with their endowments, whereas coastal provinces have been encouraged to continue to expand and upgrade export-oriented industries.

Our measure of relevant local conditions in the labor market follows a Bartik-type projection that combines the nationwide educational distribution by industry with province-specific industrial employment composition (see Bartik (1991), Blanchard and Katz (1992)). We construct a series of time-varying province-specific educational demands for various schooling levels. Specifically, the projected provincial employment for workers with education level $k$ in province $r$ in year $t\left(\hat{E}_{r t}^{k}\right)$ is the nationwide fraction of employees with education level $k$ in industry $i$ in year $t$ ( $L_{i t}^{k} / L_{i t}$ ) weighted by the province-specific distribution of local employment by industry $\left(l_{i r t} / l_{r t}\right)$ :

$$
\hat{E}_{r t}^{k}=\sum_{i} \frac{l_{i r t}}{l_{r t}} \times \frac{L_{i t}^{k}}{L_{i t}}
$$

The nationwide education composition by industry $\left(L_{i t}^{k} / L_{i t}\right.$ ) captures both the relative supply of labor force with different education levels and the contemporaneous demand for workers with the

\footnotetext{
${ }^{32}$ China's industrial policies are modelled on similar policies adopted by the Japanese government in the 1950s and 1960s, which provided various government supports to targeted industries and in particular large firms in the name of economies of scale (Beason and Weinstein (1996)).

${ }^{33}$ Che and Zhang (2018) document that firms in the manufacturing sector employed more college-educated workers and were able to adopt more advanced technologies after the higher education expansion.
} 
different skills relevant to the technology each industry is using at a given point in time. The province-industry weights $\left(l_{i r t} / l_{r t}\right)$ then aggregate the demand for different types of skills in a province based on the local industrial structure. Of course, while this index does not directly measure the demand for specific types of degrees, it can control for how overall demand intensity may affect demand for elite graduates.

In the cross-section, our local skill demand measure, $\hat{E}_{r t}^{k}$, provides an exogenous portrait of how differing industrial compositions across provinces imply varying demand for specific skill classes of workers (defined by education level). Over time, the measure incorporates the expansion of higher education coupled with the production changes by industries to utilize more skilled workers, and this is mapped into individual provincial demands. ${ }^{34}$

The Hukou registration system also helps in the identification of the effects of elite education and of employer learning. China has restricted internal migration through the household registration system (Hukou) since the 1950s. While barriers to migration were reduced since the mid-1980s, restrictions on labor mobility, especially across provinces, remain tight (Au and Henderson (2006); Chan and Zhang (1999); Chan (2019)). First, without a local Hukou, one is ineligible to work for certain sectors, industries, and occupations such as, for example, the state sector and monopolistic industries (Au and Henderson (2006); Song and Li (2013); Ma (2018)). ${ }^{35}$ Second, even though people may be hired on short-term contracts without a local Hukou, they are not eligible for local public services including basic public education for children, ${ }^{36}$ health care, and public pension. Since these programs are administered by provincial governments, they pose big obstacles for migration across provinces. The Hukou restrictions appear to have a larger impact on cross-province migration of skilled workers than that of the unskilled workers (Appleton, Song, and Xia (2014)). Thus, this national Chinese system historically has acted to limit migration and labor market adjustments outside of industrial development in each province.

\footnotetext{
${ }^{34}$ Goldsmith-Pinkham, Sorkin, and Swift (2020) introduce cautions about identification issues with the use of Bartik measures as instruments in different settings. Our use of the Bartik measures, however, is to separate differential aggregate demand across time and regions from the firm's learning adjustments. The general governmental control of regional industrial allocations in our reduced form analysis suggests less concern here.

${ }^{35}$ Each year, the government sets quotas of new Hukou and allocates them to employers for them to hire new college graduates. The allocation favors employers in industries encouraged by the industrial policies. Nonstate sector employers may obtain Hukou quotas if, for example, they are big taxpayers (Ma (2018)).

${ }^{36}$ While basic education is directly financed by city governments, children can only take the college entrance exam and be admitted to college from the province (based on the province quota) of their Hukou.
} 
The national industrial intensity of education usage $\left(L_{i t}^{k} / L_{i t}\right)$ is constructed from the Urban Household Survey (UHS) which was conducted by the Statistic Bureau of China for 1988-2009. ${ }^{37}$ The survey data are representative of registered residents in the urban area, i.e., people with Hukou and excluding migrants. Since migrant workers disproportionately work in the informal sector, our constructed industrial education composition is only for formal sector employees. In a parallel manner, we construct provincial employment, $l_{i r t} / l_{r t}$, for just formal sector employment from data in various issues of the China Statistic Yearbook and the China Labor Statistic Yearbook. Since migrant workers in general have lower education levels, our constructed provincial education composition for formal sector employees is likely to overestimate the overall percentage of college-educated labor force and underestimate that of those with low education levels. Nevertheless, the education distribution of the formal sector employment is most relevant for our study since college educated individuals are highly concentrated in the formal sector. ${ }^{38}$

We estimate Eq. 2 for the overall sample and for different age cohorts in order to compare how the dynamics of the college quality premium and returns to individual skills differ before and after the dramatic increase in the supply of college graduates due to the higher education expansion policy. In robustness analyses, we further estimate the model for individuals working in different regions and in different sectors and consider potential gender heterogeneity.

\section{$4 \quad$ Empirical Results}

This section begins with estimates of the average elite-university premium. It then turns to estimates of the dynamics of the premium with experience using the historical job data for full-time employees. All regressions control for city fixed effects.

\footnotetext{
37 The UHS data cover 9 provinces from the three broad regions of Chine (coast, center, west) for the period 1988-2006 and 16 provinces for the 2007-2009 period. The data are considered nationally representative and have been widely used to study the Chinese labor market (Zhang et al. 2005). We extrapolate data for 19801987 and 2010-2013.

${ }^{38}$ It is possible to plot the time series of our projected education demand of formal sector employees nationwide. The fractions with a middle school education and less decrease over the entire period and become quite flat in the most recent years, while the fraction with a college education or above increases over time. Interestingly, the fraction stopping with a high school education increases up to the late 1990s and then declines, concurrent to the implementation of the higher education expansion policy.
} 


\subsection{Average elite premium}

In order to benchmark our dynamic analysis and to provide a comparison with the simple labor market models, we provide estimates in Table 2 of the average premium model (Eq. 1). For this and subsequent estimates, we restrict the sample to four-year college graduates.

The estimated average return to an elite university education is 10.8 percent for the preexpansion cohort and 19.8 percent for the post-expansion cohort. This tremendous increase across cohorts, suggesting a much larger role played by college tier in the current labor market, is the starting point of our empirical analyses in the next sections. But it combines the selection component with the pure elite impact. Once Gaokao score is controlled for to account for student selection, the average return to an elite university becomes insignificant, whereas Gaokao score is a significant determinant of wages. In other words, except for the initial selection of high achieving students, the elite universities appear to add nothing to the future labor market outcomes of their students. Interestingly, the cross-sectional results also indicate that neither Gaokao score nor graduating from an elite school has a systematic impact on earnings for the pre-expansion cohort.

At this point, these results differ from much of the prior literature that finds a significant and positive wage impact of elite schools. It might be natural to conclude that graduation from elite universities provides little useful information to the market. ${ }^{39}$ But of course the cross-sectional estimates represent an amalgam of different factors including the dynamics of employer wage determination, and importantly the estimated elite effects must be tracked over the career. In particular, the standard employer learning model would suggest that the signaling impact from the reputation of elite colleges, if initially present, would progressively disappear as more precise information about the worker becomes available.

\subsection{Dynamics of elite premium and returns to individual skills}

We now focus on the dynamics of the labor market value of graduating from an elite college as described in Eq. 2 and Eq. 3. Table 3 reports the baseline estimates of how the returns to an elite university education change with labor market experience, where the elite-university estimates include returns both to selection and to other aspects of elite schools (value-added, networking, and reputational impact). All estimates are based on the constructed employment histories that are used to form panel data on the evolution of wages over the current employment spell, and all include city

\footnotetext{
${ }^{39}$ These results are, however, similar to those in Arcidiacono, Bayer, and Hizmo (2010) who conclude that firms are able to observe the productive skills of college graduates at hiring and that uncertainty only enters for high school graduates.
} 
fixed effects that control for time-constant differences across local labor markets. The dependent variable is log wages, and standard errors are clustered by province. ${ }^{40}$

The first three columns provide estimates from the most basic model of the dynamics of labor market returns, first for all workers and then separately for the pre-expansion and the post-expansion cohorts. The estimated coefficient for the elite university dummy reflects the returns to an elite university education at job entry $\left(\beta_{0}\right)$; it is significant for the entire sample. The interactions between the elite university dummy and the quadratic function of potential experience describe changes in the elite premium across the career. When we divide the sample by pre- and post-expansion period of higher education, however, we find very different results. The estimates on the interactions between the elite dummy and the quadratic function of potential experience are close to zero and insignificant for the pre-expansion cohort (col. 2), but significant, both economically and statistically, for the postexpansion cohort (col. 3). These estimates for the recent time period indicate a sharp decline in the return to elite universities at the early stage of career.

But, these initial estimates do not allow for other, possibly correlated influences on wages. The right half of Table 3 introduces our projected time and province-specific employment demand for educated labor based on the provincial industrial composition $\left(\hat{E}^{C O L}\right)$. In the pre-expansion estimates (column 5), the estimated impact of elite schools on wages now is much smaller and statistically insignificant. The clearest picture of wage dynamics is found in column 6 for the post-expansion period. The estimated elite premium at job entry and its subsequent changes with experience are significant just for the post-expansion cohort, the estimates being quite close in magnitude to those in column $3 .{ }^{41}$ The estimates on the linear and quadratic term for the post-expansion cohort (-0.086 and 0.007 , respectively) indicate that the premium to an elite university education declines rapidly in the first six to seven years of the career but recovers to some extent later in the career. ${ }^{42}$

The estimated premium to male workers is 21.3 percent for the pre-expansion cohort, but one third smaller for the post-expansion cohort. The estimates also indicate that in provinces with a larger

\footnotetext{
40 The small number of clusters raises concerns about the best way to estimate standard errors (see Angrist and Pischke (2009) and Cameron and Miller (2015)). Given the form of our empirical model, it is not feasible to use the wild cluster resampling, but we report different critical values for the clustered standard errors below.

${ }^{41}$ Cameron and Miller (2015) suggest in this case using critical values for $\mathrm{t}(13)$, which would imply p-values of $0.0003,0.024$, and 0.027 for estimates on the elite dummy and interactions between the elite dummy and the potential experience and its square (column 6 of Table 3).

42 The estimates in Table 3 use all observations. Because of some missing career information, this involves an unbalanced panel. If we rely on just the balanced panel, the dynamics of the elite college premium are qualitatively the same.
} 
demand for skilled labor, wages of college graduates are higher, and the magnitude is somewhat larger for the pre-expansion cohort.

Because we focus on the starting salary for the current job, job changing could bias our estimated dynamics. If elite university graduates are more likely to switch to better-paid jobs in the early stage of careers, we might underestimate the initial decline in the elite premium, and vice versa if ordinary university graduates change jobs more often. In our panel, 30 percent of the pre-expansion cohort have changed firms over their careers, with 28 percent for the elite university graduates and 31 percent for the ordinary university graduates. For the post-expansion cohort, the overall firmchanging rate is 22 percent, with 16 percent and 23 percent for the elite and the ordinary university graduates respectively. In order to gauge the potential bias, columns 7 and 8 present estimates for individuals who are still working in their first firm. While this has some effect during the preexpansion period, the estimates on the interactions between the elite dummy and potential experience and its square in the post-expansion cohort are almost identical to those in column 6 - which indicate that the main results are not driven by endogenous firm switching.

The dynamics of the elite premium for the post-expansion cohort point to a large initial wage premium for elite-university graduates, matching the media accounts of the more recent labor market. But, they also indicate substantial employer learning that leads to quick declines in the premium. We concentrate on the post-expansion period for the remainder of the analysis in order to understand better the employer learning component.

Our first refinement of this estimation addresses how selection affects the estimated elite university premium. In Table 4 we introduce the Gaokao admissions score, the key factor in admission to an elite university. ${ }^{43}$ Column 1 refers to the full sample and column 2 to the sample of workers still with their original firms. The Gaokao score has a statistically significant impact on wages and indicates a 16 percent increase in wages per standard deviation increase. Interestingly, the responsiveness of wages to measured achievement is very close to the developed country average impacts found in Hanushek, Schwerdt, Wiederhold, and Woessmann (2015). In simplest terms employers reward the same qualities that are used to select students for elite Chinese universities and at the same rate found elsewhere in the world.

\footnotetext{
${ }^{43}$ The number of observations in Table 4 is reduced by about 18 percent because of missing Gaokao z-scores. About half of the missing Gaokao z-scores comes from missing individual survey data. The other half reflects missing information on the maximum possible Gaokao score, which is collected from the internet and is needed for the normalization and comparison of scores. About 10 percent of ordinary university and 5 percent of elite university graduates, respectively, are missing Gaokao scores. For robustness we estimate the models in Table 3 using the same sample as in Table 4, and the results are statistically indistinguishable.
} 
Importantly, the removal of selection into the elite universities with the inclusion of the Gaokao score, while lowering the elite premium at job entry, has little impact on the pattern of employer learning. The estimated pattern of labor market responsiveness to elite university graduates is essentially the same with the admissions score in Table 4 and without the admissions score in columns 6 and 8 of Table 3 .

It is also interesting to examine the wage impact of Gaokao scores as the career progresses. The U.S. analyses of employer learning take test score measures as indicating productive factors that are unobserved by employers, leading them at initial hiring to look for observed measures that are correlated with the underlying true productivity. With time to observe actual performance of workers, firms tend to weight the observed proxy less and the unobserved true measure more. But, this is not what we observe in China. As seen in columns 3 and 4, the wage relationship with Gaokao scores is unchanged over the career, suggesting that employers do have access at hiring to additional information beyond the applicant's college tier to help determine wages. While not observed by economists, this may include information listed in the resume or revealed during interviews. ${ }^{44}$ Based on surveys of a nationally representative sample of college graduates in 2003, we find that achievements generally listed on a college graduate's resume, such as passing a higher level of national English test (Level 6), taking a second major, having received merit-based college scholarships, which are awarded based on performance during college, and having had any internship experience, are significantly associated with a higher Gaokao score, both individually and jointly. They jointly explained $64 \%$ of the variation in the standardized Gaokao score. ${ }^{45}$ This interpretation is further supported by the fact that the estimated wage impact of Gaokao scores (not shown) is virtually identical for graduates of elite universities and graduates of ordinary universities.

Figures $5 \mathrm{a}$ and $5 \mathrm{~b}$ plot the evolution of the elite premium with the same controls as in column 6 of Table 3, with and without the Gaokao score ${ }^{46}$ (Bars indicate 90 percent confidence intervals). The elite premium declines quickly up to the fifth year of potential experience, a result consistent with prior findings in the employer learning literature where most employer learning of worker productivity occurs quickly. ${ }^{47}$ Controlling for Gaokao score reduces the estimated elite premium by

\footnotetext{
${ }^{44}$ This is similar to the interpretation of U.S. data for college graduates in Arcidiacono, Bayer, and Hizmo (2010).

45 The surveys are conducted by researchers of Peking University, and the data are provided to us by Professor Changjun Yue of Peking University. Estimation results are available from the authors upon request.

${ }^{46}$ Specifically, we include interactive terms between the elite dummy and a series of indicators for 1-2 years, 35 years, 6-10 years, and 11-16 years of potential experience. Note, however, that the cell sizes in these categories become quite small, leading to imprecise estimates.

${ }^{47}$ Lange (2007) finds that it takes on average three years for any expectation errors of employers about worker productivity to decline by approximately 50 percent.
} 
roughly 10 percentage points over the entire career path, consistent with the estimate in Table 4 where returns to measured skills do not change over the career. ${ }^{48}$ The elite premium is insignificantly different from zero at the 3-5 year point.

These estimates are not, however, fully consistent with a symmetric learning model. The turnaround of the elite premium at the mid-career is more consistent with asymmetric learning and a promotion signaling model (DeVaro and Waldman (2012); Waldman (2016)). This predicts that, ceteris paribus, better educated individuals (elite university graduates here) are more likely to be promoted and hence experience later wage increases.

Our survey data allow us to go further along these lines into firm learning dynamics. We create an indicator variable promotion that equals 1 if an individual is currently in at least a mid-level manager position or professional rank and equals 0 otherwise. Elite and ordinary university graduates with less than five years of potential experience have similarly low and insignificantly different probabilities of having been promoted - 13 percent and 19 percent, respectively. After five years, however, promotion rates for elite graduates rise to 53 percent, significantly larger (at 1 percent level) than the 39 percent for ordinary university graduates. This pattern continues to hold in regression analyses that control for gender, Gaokao score, and city fixed effects. ${ }^{49}$ Since we do not have information on the exact timing of individual promotions, this is not a direct test of the promotion signaling model, but it does suggest that the signaling role of an elite university education evolves over the career in a more complex manner and warrants further study.

The pattern of the elite premium and the returns to measured skills might reflect differential patterns of occupational and industry choices across university types, but that does not appear to be the case. In Table 5, we include a full set of fixed effects for the industry, occupation, and sector of employment to investigate the potential channels for the wage dynamics. ${ }^{50}$ The results for both the elite premium dynamics and the impact of selection (Gaokao score) are remarkably unchanged. They

\footnotetext{
${ }^{48}$ Potentially stronger social networks of the elite graduates might enable these students both to receive lucrative job offers at the entry and to receive promotions at the mid-career (Granovetter (1973); Montgomery (1991)), but models of social network alone do not appear to be sufficient to explain the entire dynamics of the wage growth.

${ }^{49}$ The estimation results are available from the authors upon request.

${ }^{50}$ Sectors include government agencies, public institutions, state-owned enterprises (SOEs), and firms and small businesses of all other ownerships. Occupation and industry are identified essentially at the one-digit level. Industries include: Agriculture and mining; Electricity, gas and water; Manufacturing; Construction; Transport, storage, post and telecom and IT; Wholesale and retail trade and catering services; Finance and insurance; Real estate; Social services; Health, education, culture and research; and Party and Government organs and social organizations. Occupations include: Leading cadres; Professional and technical staff; Office workers; Service workers; and Production workers. The sample includes individuals who report complete information about the industry, occupation, and sector of their jobs.
} 
are also robust to changing the estimation sample to individuals who have never changed firms (column 5). In other words, the initial elite premium combined with its variation due to employer learning appears to be a pervasive fact of the urban Chinese labor market and holds within broad occupational and industry categories.

Table 6 examines aspects of the overall specification in more detail. First, we divide the sample into those with just a bachelor's degree and those with a master's degree. The bachelor's degree sample (column 1) is uniformly very similar to the prior baseline results, but the very small master's degree sample (column 2) indicates an insignificant effect of elite university graduation (measured at the completion of the bachelor's degree).

We also look in more detail at provincial differences in the rate of expansion of college graduates. ${ }^{51}$ We see in column 3 that the importance of graduating from an elite university is noticeably greater in regions with above average rates of college admissions expansions as compared to those with below average expansions (column 4) where the elite university premium becomes insignificant. At the same time, while the initial wage offer appears to respond to the degree of expansion, employer learning is more rapid in provinces with above average expansion.

We go further to understand the intensity of demand for human capital. We use the national human capital intensity by industry from Eq. 4 but weight this by the relative value-added in each province-industry cell to get a measure of human capital demand intensity. In columns 5 and 6, we divide provinces by above and below median industry intensity and re-estimate the basic equations. We again see that the elite premium is larger in provinces where the industry demand for human capital is high, but there is also stronger employer learning and hence faster declines in the elite premium in these provinces.

We also include city-specific time trends to capture time varying labor market developments that differ across cities. The results (column 7) are very similar to those for the basic model where there is a significant premium for graduation from an elite university but also strong employer learning that leads to rapid declines in the average premium. The effect of selective admissions scores remains similar to that previously found.

In the most demanding estimation, we estimate the models of Table 4 controlling for individual fixed effects, where identification comes solely from within-individual differences. ${ }^{52}$ This approach relies heavily on the two observations of career data for each individual, but it offers the

\footnotetext{
${ }^{51}$ For this we compare the provincial growth of college admissions since 1995 to the national growth of college admissions since 1995.

52 The main effects of elite college attendance and Gaokao score are subsumed by the individual fixed effect.
} 
possibility of removing individual-specific factors that are constant over time including ability, motivation, family background, and the like. The key employer learning components reported in Table 6 are similar to those in Table 4. Similarly, the impact of Gaokao scores shows no significant pattern over time (not reported). In short, while this is not a strong test, there is no evidence that employer learning effects are driven by unmeasured individual characteristics.

\subsection{Variations by Degree of Marketization and Sector}

The underlying model behind this analysis is that employers are driven by profit maximization that pushes them to pay wages in line with productivity. Given China's vast regional heterogeneity in economic and market forces, we might expect spatial heterogeneity in the dynamics of wage setting. Here we consider variations in returns to skills and in the elite university premia, again for the post-expansion cohort.

To assess the influence of differential market forces, we estimate the basic model of Table 4 for the post-expansion cohort in different geographical regions defined by alternative measures of local economic development (Table 7). We first compare coastal and inland regions, where the coastal regions are more economically developed and have more competitive markets. ${ }^{53}$ While the picture of the elite university premium in coastal regions mirrors that seen in the previous employer learning models in both magnitude and statistical significance (col. 1), the estimates for the less developed inland region (col. 2) are much smaller in magnitude and statistically insignificant. Further, the estimate of returns for the Gaokao score is large (0.2) and significant at the 1 percent level for the coastal region but is much smaller (0.125) for the inland region, even though still significant at the 5 percent level.

The remaining columns of Table 7 use alternative, more city-specific measures of development: the share of services in output (col. 3-4) and the share of agriculture in output (col. 5-6) where more services and less agriculture are signs of greater economic development. Uniformly, more economically developed cities show large initial premia for elite university graduates but also rapid employer learning about individual productivity. More skilled individuals (as measured by Gaokao score) also receive strong returns in these cities. Less developed cities (col. 4 and 5) show very low returns for Gaokao scores and, while the patterns of elite premia seen before hold, the estimates are all statistically insignificant.

\footnotetext{
53 The coastal region includes Beijing, Jiangsu, Shandong, and Guangdong provinces in our sample. The inland region includes the remaining 10 provinces: Shanxi, Liaoning, Anhui, Henan, Hubei, Hunan, Chongqing, Sichuan, Yunnan, and Gansu.
} 
Table 8 turns to how wage settings may vary with foreign direct investment (FDI). The size of the foreign sector is measured by the value-added share of foreign-owned firms in a city in the first two columns and by the percentage of foreign-owned firms relative to the total number of firms in a city in the remaining two columns. While the results for the elite premia do not systematically vary across the cities by the concentration of FDI, the returns to Gaokao scores are systematically stronger and statistically significant in the top half of the foreign investment distribution but not the bottom half.

To summarize, estimates in Tables 7 and 8 generally suggest that skills are more highly valued at locations with more developed economies and markets. Further, the patterns of significant elite university premia with strong and asymmetric employer learning are much more prevalent in the more developed cities.

A final way of viewing wage setting in China is to compare the labor market dynamics in the public and private sectors. A natural hypothesis is that the private sector employers, under more competitive pressure, will set wages based more on individual productivity, and hence the dynamics of the elite university premium should be more pronounced. Table 9 reports the estimation results where state-owned enterprises (SOEs) are alternately treated as more like private firms (col. 2) versus more like public firms (col. 3). The public sector includes just purely government agencies and public institutions such as schools, universities, and hospitals (col. 1).

Estimates for the impact of college tier follow the previous patterns - more competitive employers initially bid for elite graduates but then quickly adjust wages to observed productivity. Interestingly, both public and private employers consistently provide high returns to the skills underlying university selection (Gaokao score). The strong estimate for the public sector, although not statistically significant, is consistent with the general observation that public sector employers are also highly selective in hiring. For example, applicants need to pass a written exam and then go through rounds of interviews to receive a civil service job offer, and the competition has become more intense since the higher education expansion. Schools, universities, and hospitals with better performance get better reputations and in turn receive more resources from both the government and private contributions. They therefore have a strong incentive to hire highly capable individuals.

\section{Conclusions}

The Chinese labor market has undergone a remarkable transformation over the past two decades. While the rapid growth of the economy is well-known, the transformation of the labor force is less appreciated. Beginning in 1999, the government instituted a dramatic expansion of higher education admissions. This expansion altered the role and importance of elite universities and provides a unique opportunity to look at employer learning in the labor market. 
Using a representative sample of urban workers, we examine how the market changed with the expansion of colleges and universities. At the same time, we control for exogenous changes in the demand for skills due to technological progress in the Chinese economy, taking advantage of the remaining planned features of the economy arising from government industrial policies and the Hukou restrictions. We use employment histories to construct a panel data set that permits identifying both elite college premia at entry and the dynamics of these premia as employers have a chance to observe actual productivity of workers. We also incorporate a more general skill measure - the Gaokao score that is used in college selection.

We find a substantial premium to attending an elite university, but this premium erodes rather quickly as the employer learns about the worker's capabilities. It increases again at the mid-career, suggesting asymmetric learning about skills across employers. These patterns hold strongly for postexpansion workers entering the labor market after the higher education expansion, but not for preexpansion workers. The labor market does reward the skills measured in university selection, but adjustment for selection does not eliminate an initial labor market premium for elite university graduates. Employers seem to recognize differences in these cognitive skills at hiring through general application and interview information. Interestingly, they reward higher Gaokao scores of elite and ordinary university graduates equally.

Importantly, including explicit measures of university selection scores does not change the dynamics of the elite-college premium. Moreover, the pattern of labor market returns of attending an elite college are found across the economy and are not restricted to specific industries, occupations, or employment sectors (public or private). They are, however, more important in more competitive parts of the economy. 


\section{References}

Aghion, Philippe, Jing Cai, Mathias Dewatripont, Luosha Du, Ann Harrison, and Patrick Legros. 2015. "Industrial Policy and Competition." American Economic Journal: Macroeconomics 7, no. 4 (October): 1-32.

Altonji, Joseph G., and Charles R. Pierret. 2001. "Employer learning and statistical discrimination." Quarterly Journal of Economics 116, no. 1 (February): 313-350.

Anelli, Massimo. 2020. "The Returns to Elite University Education: a Quasi-Experimental Analysis." Journal of the European Economic Association 18, no. 6: 2824-2868.

Angrist, Joshua D., and Jörn-Steffen Pischke. 2009. Mostly harmless econometrics: An empiricist's companion. Princeton, NJ: Princeton University Press.

Appleton, Simon, Lina Song, and Qingjie Xia. 2014. "Understanding Urban Wage Inequality in China 1988-2008: Evidence from Quantile Analysis." World Development 62(October): 1-13.

Araki, Shota, Daiji Kawaguchi, and Yuki Onozuka. 2016. "University prestige, performance evaluation, and promotion: Estimating the employer learning model using personnel datasets." Labour Economics 41(Auguat): 135-148.

Arcidiacono, Peter, Patrick Bayer, and Aurel Hizmo. 2010. "Beyond signaling and human capital: Education and the revelation of ability." American Economic Journal: Applied Economics 2, no. 4 (October): 76-104.

$\mathrm{Au}$, Chun-Chung, and J. Vernon Henderson. 2006. "How migration restrictions limit agglomeration and productivity in China." Journal of Development Economics 80, no. 2 (August): 350-388.

Barrera-Osorio, Felipe, and Hernando Bayona-Rodríguez. 2019. "Signaling or better human capital: Evidence from Colombia." Economics of Education Review 70(June): 20-34.

Bartik, Timothy J. 1991. Who Benefits from State and Local Economic Development Policies? Kalamazoo, MI: W.E. Upjohn Institute for Employment Research.

Beason, Richard, and David E. Weinstein. 1996. "Growth, Economies of Scale, and Targeting in Japan (1955-1990)." The Review of Economics and Statistics 78, no. 2 (May): 286-295.

Bernhardt, Dan. 1995. "Strategic Promotion and Compensation." The Review of Economic Studies 62, no. 2 (April): 315-339.

Black, Dan A., and Jeffrey A. Smith. 2004. "How robust is the evidence on the effects of college quality? Evidence from matching." Journal of Econometrics 121, no. 1-2 (July-August): 99124.

Black, Dan A., and Jeffrey A. Smith. 2006. "Estimating the Returns to College Quality with Multiple Proxies for Quality." Journal of Labor Economics 24, no. 3: 701-728.

Black, Sandra E., Jeffrey T. Denning, and Jesse Rothstein. 2023. "Winners and Losers? The Effect of Gaining and Losing Access to Selective Colleges on Education and Labor Market Outcomes." American Economic Journal: Applied Economics 15, no. 1 (January): 26-67.

Blanchard, Olivier, and Lawrence F Katz. 1992. "Regional evolutions." Brookings Papers on Economic Activity 1: 1-75.

Bleemer, Zachary. 2021. "Affirmative Action, Mismatch, and Economic Mobility after California's Proposition 209." The Quarterly Journal of Economics 137, no. 1: 115-160.

Bordón, Paola, and Breno Braga. 2020. "Employer learning, statistical discrimination and university prestige." Economics of Education Review 77(August): 101995.

Brandt, Loren, and Carsten Holz. 2006. "Spatial Price Differences in China: Estimates and Implications." Economic Development and Cultural Change 55, no. 1 (October): 43-86.

Broecke, Stijn. 2012. "University selectivity and earnings: Evidence from UK data on applications and admissions to university." Economics of Education Review 31, no. 3 (June): 96-107.

Cameron, A. Colin, and Douglas L. Miller. 2015. "A Practitioner's Guide to Cluster-Robust Inference." Journal of Human Resources 50, no. 2 (Spring): 317-372.

Castex, Gonzalo, and Evgenia Kogan Dechter. 2014. "The Changing Roles of Education and Ability in Wage Determination." Journal of Labor Economics 32, no. 4 (October): 685-710. 
Chan, Kam Wing. 2019. "China's Hukou System at 60: Continuity and Reform." In Handbook on Urban Development in China, edited by Ray Yep, Jun Wang, and Thomas Johnson. Cheltenham and Camberley, UK: Edwar Elgar: 59-79.

Chan, Kam Wing, and Li Zhang. 1999. "The Hukou System and Rural-Urban Migration in China: Processes and Changes." The China Quarterly 160(December): 818-855.

Che, Yi, and Lei Zhang. 2018. "Human Capital, Technology Adoption and Firm Performance: Impacts of China's Higher Education Expansion in the Late 1990s." The Economic Journal 128, no. 614: 2282-2320.

Cohodes, Sarah R., and Joshua S. Goodman. 2014. "Merit aid, college quality, and college completion: Massachusetts' Adams Scholarship as an in-kind subsidy." American Economic Journal: Applied Economics 6, no. 4: 251-285.

Dale, Stacy Berg, and Alan B. Krueger. 2002. "Estimating the Payoff to Attending a More Selective College: An Application of Selection on Observables and Unobservables." Quarterly Journal of Economics 117, no. 4: 1491-1527.

Dale, Stacy Berg, and Alan B. Krueger. 2014. "Estimating the Effects of College Characteristics over the Career Using Administrative Earnings Data." Journal of Human Resources 49, no. 2 (March 31, 2014): 323-358.

Daugherty, Lindsay, Paco Martorell, and Isaac McFarlin. 2014. "Percent plans, automatic admissions, and college outcomes." IZA Journal of Labor Economics 3, no. 1 (2014/10/22): 10.

DeVaro, Jed, and Michael Waldman. 2012. "The Signaling Role of Promotions: Further Theory and Empirical Evidence." Journal of Labor Economics 30, no. 1 (January): 91-147.

Farber, Henry S., and Robert Gibbons. 1996. "Learning and Wage Dynamics." The Quarterly Journal of Economics 111, no. 4 (November): 1007-1047.

Feng, Shuaizhang, and Xiaoyu Xia. 2022. "Heterogeneous firm responses to increases in high-skilled workers: Evidence from China's college enrollment expansion." China Economic Review 73(June): 101791.

Goldin, Claudia, and Lawrence F. Katz. 2008. The race between education and technology. Cambridge, MA: Harvard University Press.

Goldsmith-Pinkham, Paul, Isaac Sorkin, and Henry Swift. 2020. "Bartik Instruments: What, When, Why, and How." American Economic Review 110, no. 8: 2586-2624.

Granovetter, Mark S. 1973. Getting a job: A study of contacts and careers. Cambridge, MA: Harvard University Press.

Hanushek, Eric A., Guido Schwerdt, Simon Wiederhold, and Ludger Woessmann. 2015. "Returns to skills around the world: Evidence from PIAAC." European Economic Review 73: 103-130.

Hastings, Justine S., Christopher A. Neilson, and Seth D. Zimmerman. 2014. "Are Some Degrees Worth More than Others? Evidence from college admission cutoffs in Chile." NBER Working Paper 19241. Cambridge, MA: National Bureau of Economic Research (September).

Heilmann, Sebastian, and Lea Shih. 2013. "The Rise of Industrial Policy in China, 1978-2012." Harvard-Yenching Institute Working Paper Series Cambridge, MA: Harvard University (January).

Hoekstra, Mark. 2009. "The Effect of Attending the Flagship State University on Earnings: A Discontinuity-Based Approach." Review of Economics and Statistics 91, no. 4: 717-724.

Jia, Ruixue, and Hongbin Li. 2021. "Just above the exam cutoff score: Elite college admission and wages in China." Journal of Public Economics 196(April): 104371.

Jiang, Feitao, and Xiaoping Li. 2018. "China's Industrial Policies during the Economic Reform of the Past Forty Years." Management World 10(in Chinese): 73-85

Kang, Lili, Fei Peng, and Yu Zhu. 2021. "Returns to higher education subjects and tiers in China Evidence from the China Family Panel Studies." Studies in Higher Education 46, no. 8: 16821695. 
Kaufmann, Katja, Matthias Messner, and Alex Solis. 2015. "Returns to Elite Higher Education in the Marriage Market: Evidence from Chile." IGIER (Innocenzo Gasparini Institute for Economic Research) Milan: Bocconi University (July).

Knight, John, Quheng Deng, and Shi Li. 2017. "China's expansion of higher education: The labour market consequences of a supply shock." China Economic Review 43(April): 127-141.

Lang, Kevin, and Erez Siniver. 2011. "Why is an elite undergraduate education valuable? Evidence from Israel." Labour Economics 18, no. 6 (December): 767-777.

Lange, Fabian. 2007. "The Speed of Employer Learning." Journal of Labor Economics 25, no. 1: 1-35.

$\mathrm{Li}$, Hongbin, Lingsheng Meng, Xinzheng Shi, and Binzhen Wu. 2012. "Does attending elite colleges pay in China?" Journal of Comparative Economics 40, no. 1 (February): 78-88.

Liu, Zhiqiang. 1998. "Earnings, Education, and Economic Reforms in Urban China." Economic Development and Cultural Change 46, no. 4 (July): 697-725.

$\mathrm{Ma}$, Xinxin. 2018. "Labor market segmentation by industry sectors and wage gaps between migrants and local urban residents in urban China." China Economic Review 47(February): 96-115.

MacLeod, W. Bentley, Evan Riehl, Juan E. Saavedra, and Miguel Urquiola. 2017. "The Big Sort: College Reputation and Labor Market Outcomes." American Economic Journal: Applied Economics 9, no. 3: 223-261.

Mansour, Hani. 2012. "Does Employer Learning Vary by Occupation?" Journal of Labor Economics 30, no. 2 (April): 415-444.

Montgomery, James D. 1991. "Social Networks and Labor-Market Outcomes: Toward an Economic Analysis." The American Economic Review 81, no. 5 (December): 1408-1418.

Schönberg, Uta. 2007. "Testing for Asymmetric Employer Learning." Journal of Labor Economics 25, no. 4: 651-691.

Song, Jin, and Shi Li. 2013. "China's Integrated Urban-Rural Hukou Reform and Occupation Distribution." World Economy 7: 28-47 (in Chinese).

Waldman, Michael. 2016. "The dual avenues of labor market signaling." Labour Economics 41(August): 120-134.

Wu, Jinglian. 2018. The Progression of the Chinese Economic Reform: Encyclopedia of China Publishing House (in Chinese).

Zhang, Junsen, Yaohui Zhao, Albert Park, and Xiaoqing Song. 2005. "Economic returns to schooling in urban China, 1988 to 2001." Journal of Comparative Economics 33, no. 4 (December): 730752.

Zhang, Lei. 2009. "A value-added estimate of higher education quality of US states." Education Economics 17, no. 4 (December): 469 - 489.

Zhong, Hai. 2011. "The impact of population aging on income inequality in developing countries: Evidence from rural China." China Economic Review 22, no. 1 (June): 98-107.

Zimmerman, Seth D. 2019. "Elite Colleges and Upward Mobility to Top Jobs and Top Incomes." American Economic Revew 109, no. 1: 1-47. 


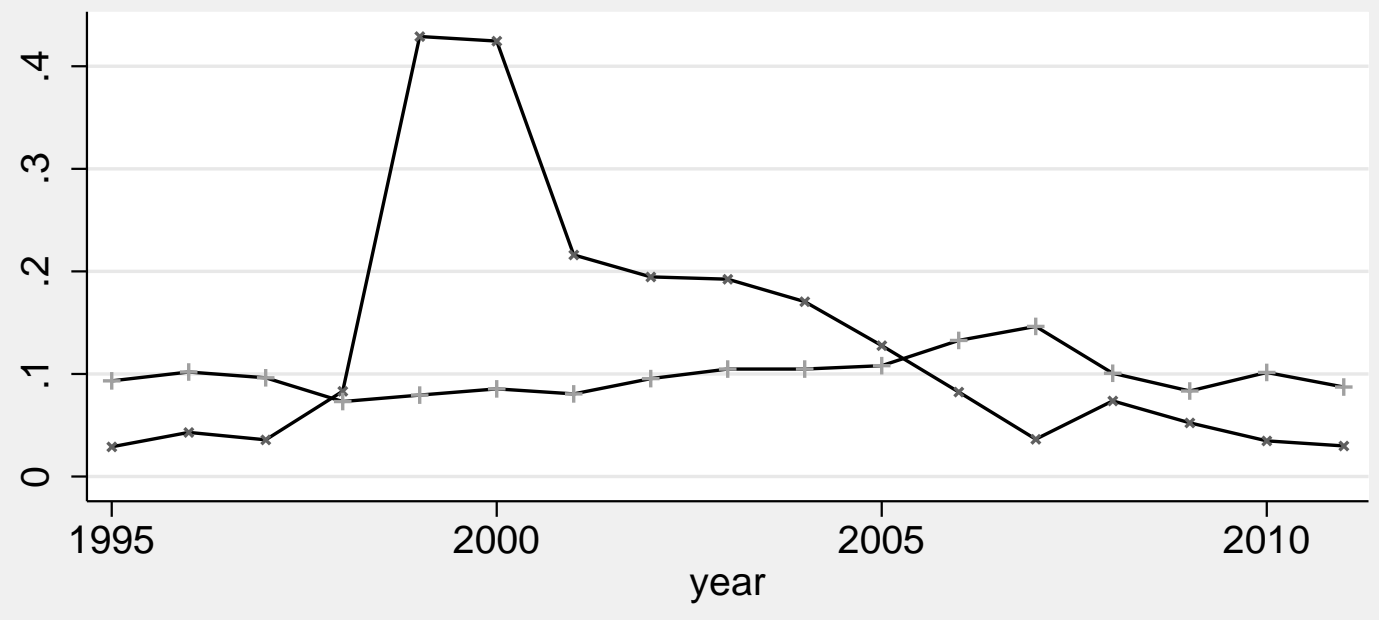

annual growth rate of college admission annual growth rate of GDP

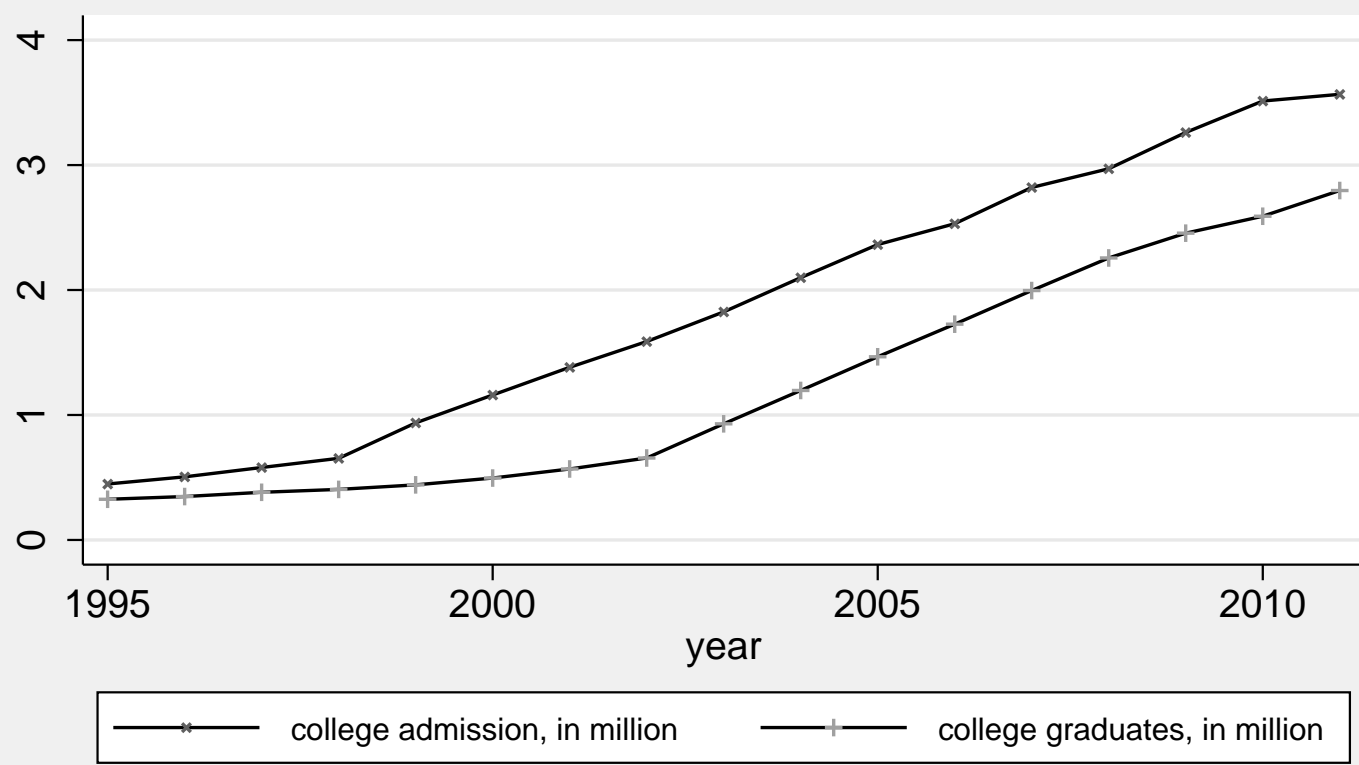

Notes: The top panel plots the annual growth rate of college admission, equal to the increase in the number of students admitted to 3- or 4-year regular colleges between the current year and previous year divided by the number for the previous year, and the annual growth rate of GDP. The bottom panel depicts the total number of students (in million) admitted to regular 4-year programs in colleges and universities and the total number of graduates from regular 4-year college programs. Data come from various issues of China Statistics Yearbook and China Education Statistics Yearbook. 
Figure 2: College Admission by College Type (log scale)

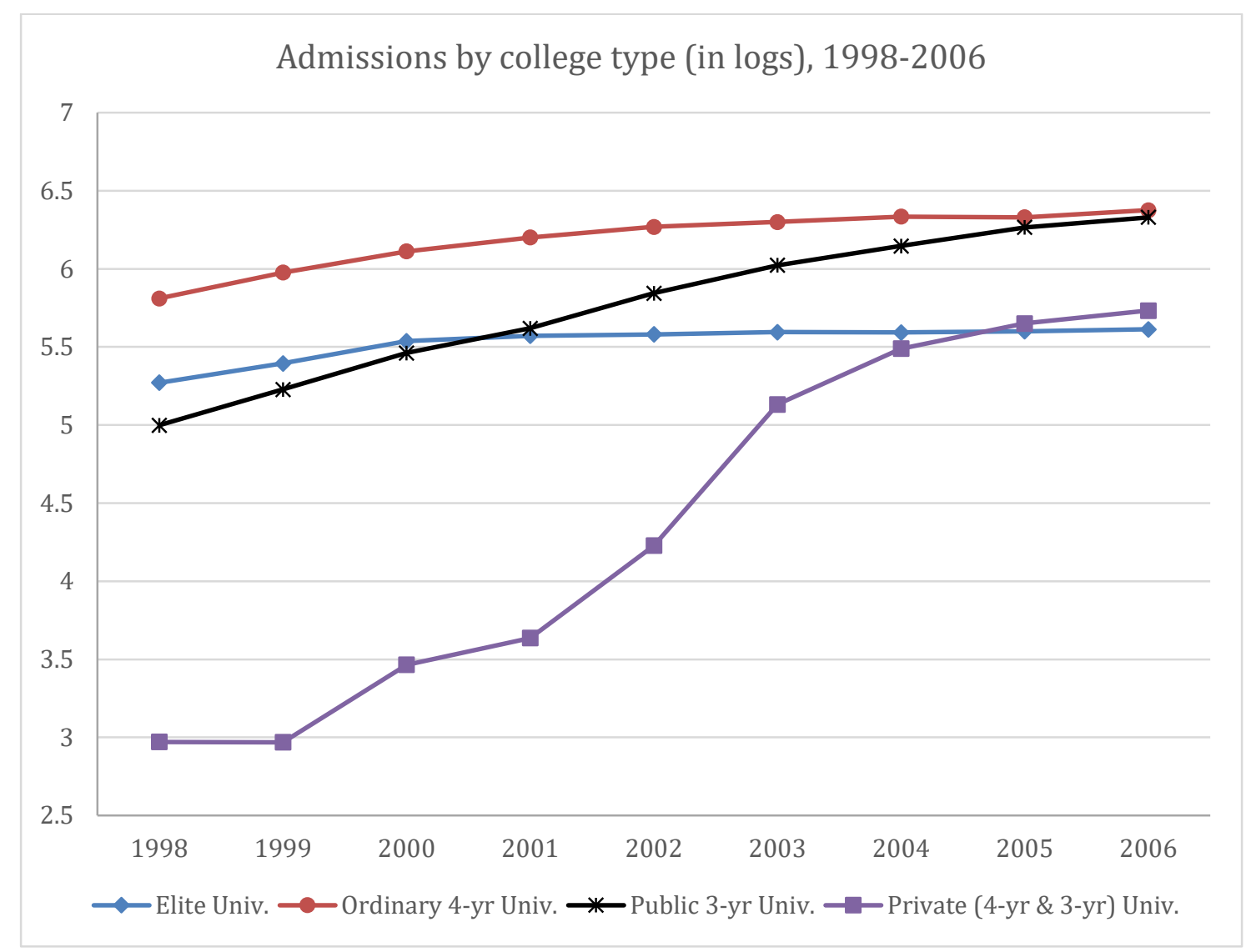

Notes: The figure depicts the logarithm of the total annual number of students admitted (in thousands) by college type. The college types are elite universities, ordinary 4-year universities, public 3-year universities and private universities (offering both 3-year and 4-year programs). Data come from the Ministry of Education of China. 
Figure 3: College Inputs by College Type

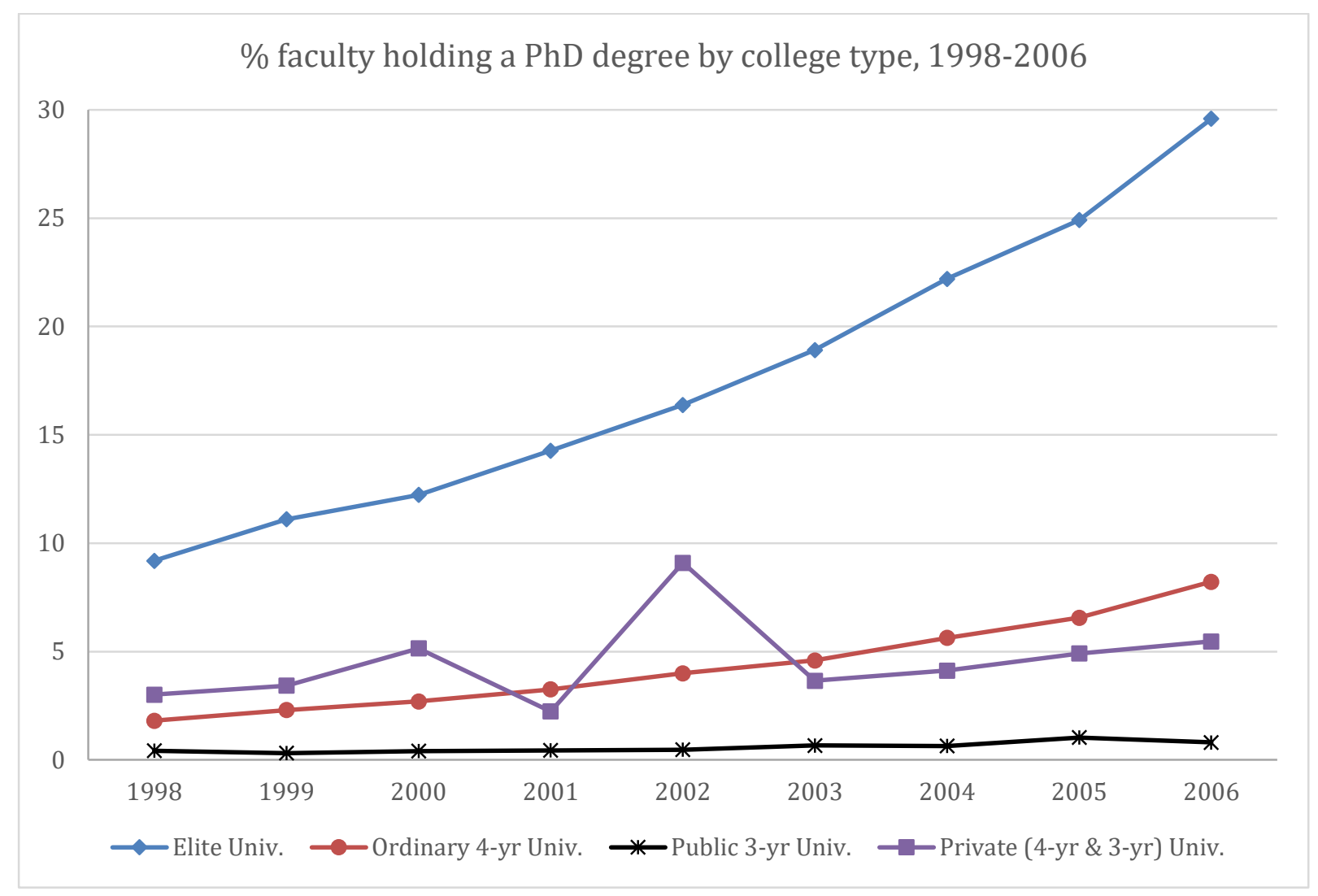

Notes: The figure depicts the share of faculty with a $\mathrm{PhD}$ degree by college type. The college types are elite universities, ordinary 4-year universities, public 3-year universities and private universities (offering both 3-year and 4-year programs). Data come from the Ministry of Education of China. 

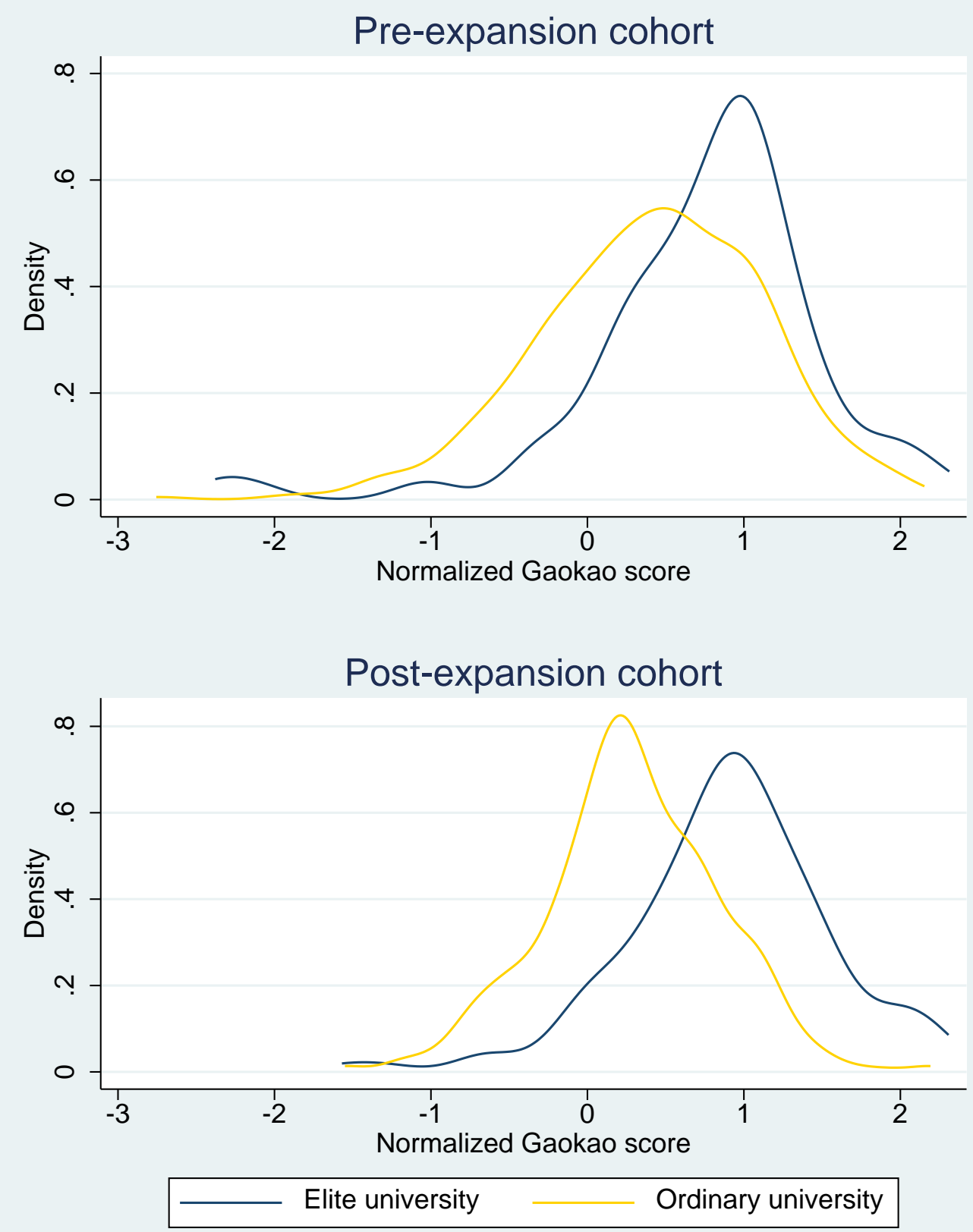

Notes: The sample includes all full-time workers with hourly wage between 1 and 100 Yuan and a four-year college degree, aged 20 to 60. The post-expansion cohort sample refers to individuals born in or after 1980 (142 and 467 graduates from elite and ordinary universities respectively); the pre-expansion cohort sample to individuals born between 1953 and 1979 (117 and 423 graduates from elite and ordinary universities respectively). The Gaokao score is normalized first by the maximum possible score of each test and then transformed to a z-score with mean zero and standard deviation of one. Authors' calculation from the China Household Income Project 2013. Maximum scores come from various Gaokao-related websites. 
Figure 5a: Elite University Premium By Potential Experience for the Postexpansion Cohort (without Gaokao score)

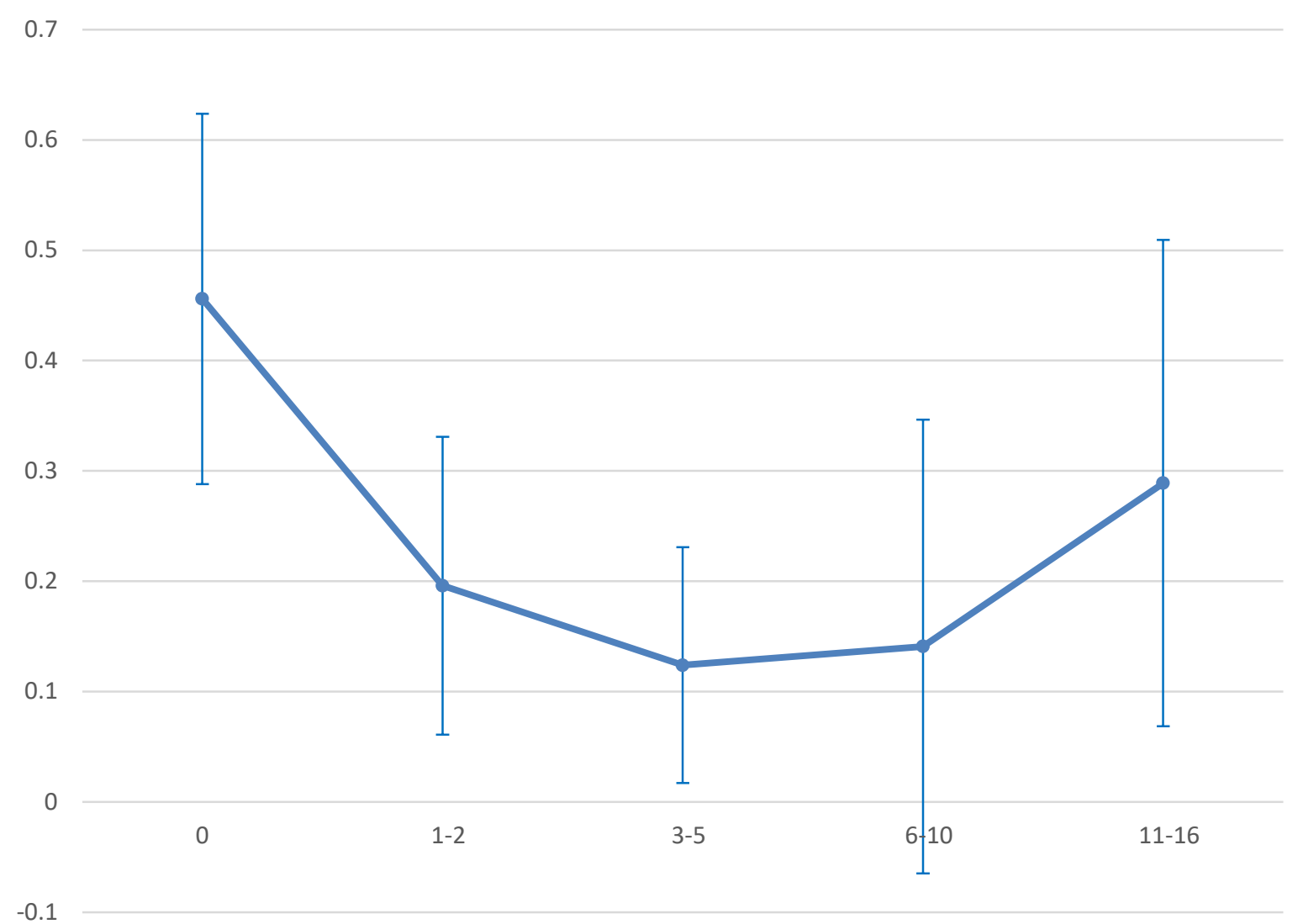

Notes: The figure depicts the coefficient estimates of interaction terms between the elite dummy and indicators for $0,1-2,3-5,6-10$, and 11-16 years of potential experience, using controls similar to those in column 6 of Table 3 and column 3 of Table 4. Bars indicate 90 percent confidence bounds. Full regression results are available from the authors upon request. The panel data sample includes all full-time workers with hourly wage between 1 and 100 Yuan and a four-year college degree, for the post-expansion cohort (individuals born in or after 1980). Dependent variable is the natural logarithm of monthly CPI-adjusted wage, measured in 2013 and in the year when one starts the current job. 
Figure 5b: Elite University Premium By Potential Experience for the Postexpansion Cohort (with Gaokao score)

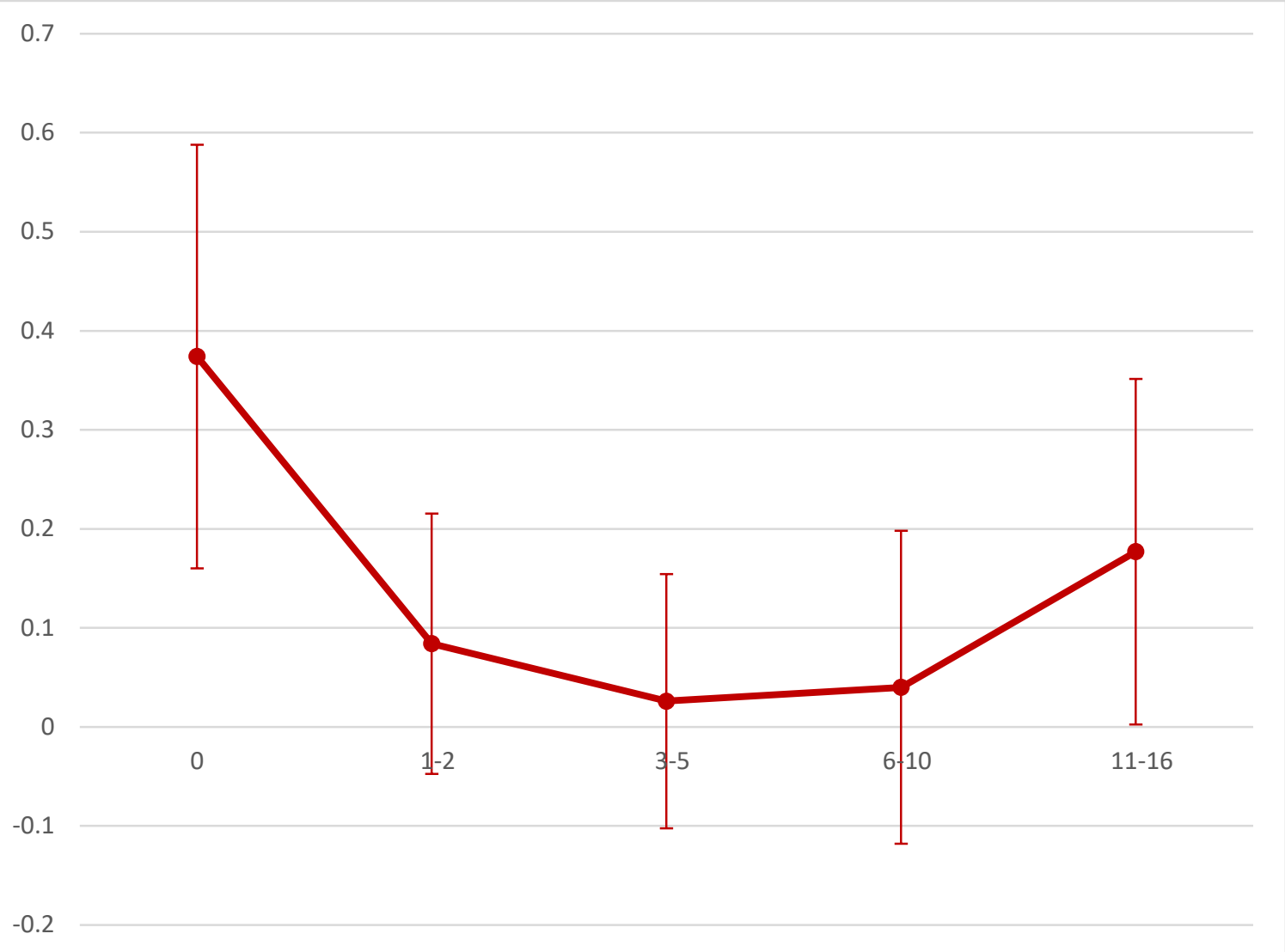

Notes: The figure depicts the coefficient estimates of interaction terms between the elite dummy and indicators for $0,1-2,3-5,6-10$, and 11-16 years of potential experience, using controls similar to those in column 6 of Table 3 and column 3 of Table 4 . Bars indicate 90 percent confidence bounds. Full regression results are available from the authors upon request. The panel data sample includes all full-time workers with hourly wage between 1 and 100 Yuan and a four-year college degree, for the post-expansion cohort (individuals born in or after 1980). Dependent variable is the natural logarithm of monthly CPI-adjusted wage, measured in 2013 and in the year when one starts the current job. 
Table 1: Distribution of Education Attainment and Employment Sector (percent)

Panel A: Educational Distribution by Age Cohort (in \%)

\begin{tabular}{cccccccc}
\hline & & \multicolumn{3}{c}{ Pre-expansion cohort } & \multicolumn{3}{c}{ Post-expansion cohort } \\
\cline { 3 - 8 } Education level & Total & Total & Female & Male & Total & Female & Male \\
\hline Primary school or less & 4.8 & 6.2 & 7.3 & 5.3 & 1.2 & 1.4 & 1.0 \\
Middle school & 25.2 & 29.2 & 29.1 & 29.3 & 15.1 & 14.1 & 16.1 \\
High school & 18.1 & 20.4 & 20.2 & 20.5 & 12.3 & 11.9 & 12.8 \\
Technical high school & 11.6 & 10.5 & 11.6 & 9.7 & 14.5 & 12.6 & 16.3 \\
Technical college & 17.8 & 15.5 & 15.0 & 15.9 & 23.5 & 25.0 & 22.2 \\
University & 22.5 & 18.2 & 16.8 & 19.3 & 33.3 & 35.0 & 31.6 \\
University breakdown & & & & & & & \\
\hline Elite university & 16.9 & 17.4 & 14.7 & 19.1 & 16.4 & 15.3 & 17.5 \\
Ordinary university & 83.1 & 82.6 & 85.3 & 80.9 & 83.6 & 84.7 & 82.5 \\
\hline
\end{tabular}

Panel B: Public Sector Share of Employment by Education

\begin{tabular}{lcccccc}
\hline & \multicolumn{3}{c}{ \% public sector } & \multicolumn{2}{c}{$\begin{array}{c}\text { \% of public sector workers in } \\
\text { government and institutions }\end{array}$} \\
\cline { 2 - 7 } Education level & Total & $\begin{array}{c}\text { Pre- } \\
\text { expansion }\end{array}$ & $\begin{array}{c}\text { Post- } \\
\text { expansion }\end{array}$ & Total & $\begin{array}{c}\text { Pre- } \\
\text { expansion }\end{array}$ & $\begin{array}{c}\text { Post- } \\
\text { expansion }\end{array}$ \\
\hline Primary school or less & 12.5 & 12.2 & 16.1 & 5.0 & 5.4 & 0.0 \\
Middle school & 24.5 & 27.0 & 12.2 & 7.4 & 7.8 & 5.4 \\
High school & 38.0 & 41.9 & 21.3 & 14.0 & 15.8 & 6.6 \\
Technical high school & 47.9 & 56.4 & 32.0 & 22.5 & 26.8 & 14.4 \\
Technical college & 58.9 & 67.6 & 44.4 & 32.4 & 40.6 & 18.6 \\
University & 73.4 & 80.9 & 62.9 & 52.8 & 61.9 & 40.2 \\
$\quad$ University breakdown & & & & & & \\
\hline Elite university & 69.4 & 72.2 & 66.5 & 43.3 & 46.0 & 40.5 \\
Ordinary university & 62.1 & 72.1 & 52.7 & 39.6 & 50.5 & 29.5 \\
\hline
\end{tabular}

Notes: The sample includes all full-time workers with hourly wage between 1 and 100 Yuan per hour, aged 20 to 60. The post-expansion cohort sample refers to individuals born in or after 1980; the pre-expansion cohort sample individuals born between 1953 and 1979. Public sector includes government agencies, institutions, and state-owned enterprises (SOEs). The three columns on the right exclude SOEs. Authors' calculation from the China Household Income Project 2013. 
Table 2: Average Premia for Elite University Graduation

\begin{tabular}{|c|c|c|c|c|c|c|}
\hline & 1 & 2 & 3 & 4 & 5 & 6 \\
\hline & All & $\begin{array}{c}\text { Pre- } \\
\text { expansion }\end{array}$ & $\begin{array}{c}\text { Post- } \\
\text { expansion }\end{array}$ & All & $\begin{array}{c}\text { Pre- } \\
\text { expansion }\end{array}$ & $\begin{array}{c}\text { Post- } \\
\text { expansion }\end{array}$ \\
\hline \multirow[t]{2}{*}{ Elite } & $0.147 * * *$ & $0.108^{* *}$ & $0.198 * * *$ & 0.092* & 0.091 & 0.061 \\
\hline & {$[0.040]$} & [0.051] & {$[0.066]$} & [0.048] & [0.061] & [0.081] \\
\hline \multirow{2}{*}{$\begin{array}{l}\text { Gaokao z- } \\
\text { score }\end{array}$} & & & & $0.106 * * *$ & 0.056 & $0.179 * * *$ \\
\hline & & & & {$[0.028]$} & [0.035] & {$[0.054]$} \\
\hline \multirow[t]{2}{*}{ PE } & $0.068 * * *$ & $0.051^{* *}$ & $0.093 * * *$ & $0.072^{* * *}$ & $0.058^{* *}$ & $0.098 * * *$ \\
\hline & {$[0.007]$} & {$[0.022]$} & [0.030] & {$[0.008]$} & {$[0.026]$} & [0.034] \\
\hline \multirow[t]{2}{*}{$\mathrm{PE}^{2}$} & $-0.001 * * *$ & $-0.001^{* *}$ & $-0.005^{* *}$ & $-0.002 * * *$ & $-0.001 * *$ & $-0.005^{* *}$ \\
\hline & {$[0.000]$} & {$[0.001]$} & {$[0.002]$} & {$[0.000]$} & [0.001] & {$[0.002]$} \\
\hline \multirow[t]{2}{*}{ Male } & $0.145^{* * *}$ & $0.199 * * *$ & $0.126^{* * *}$ & $0.159 * * *$ & $0.207 * * *$ & $0.143^{* * *}$ \\
\hline & [0.031] & {$[0.041]$} & {$[0.046]$} & [0.035] & [0.049] & {$[0.050]$} \\
\hline \multirow[t]{2}{*}{ Constant } & $7.883^{* * *}$ & $8.022 * * *$ & $7.915^{* * *}$ & $7.835^{* * *}$ & $7.976^{* * *}$ & $7.829 * * *$ \\
\hline & [0.054] & {$[0.225]$} & {$[0.105]$} & {$[0.060]$} & {$[0.270]$} & {$[0.121]$} \\
\hline $\begin{array}{l}\text { City fixed } \\
\text { effects }\end{array}$ & Yes & Yes & Yes & Yes & Yes & Yes \\
\hline Observations & 1,470 & 717 & 753 & 1,159 & 549 & 610 \\
\hline R-squared & 0.365 & 0.347 & 0.368 & 0.400 & 0.369 & 0.438 \\
\hline
\end{tabular}

Notes: The sample includes all full-time workers with hourly wage between 1 and 100 Yuan per hour and a four-year college degree, aged 20 to 60 . The post-expansion cohort sample refers to individuals born in or after 1980; the pre-expansion cohort sample individuals born between 1953 and 1979. Dependent variable is the natural logarithm of monthly CPI-adjusted wage in 2013. Explanatory variables include a dummy variable (Elite) for elite university graduates, the Gaokao score (normalized first by the maximum possible of the test one took, and then to a z-score with mean zero and standard deviation of one), potential experience ( $P E=$ Ageyears of schooling-6) and its square $\left(P E^{2}\right)$, a dummy for male workers, and city fixed effects. Robust standard errors are in brackets. Significance levels: ${ }^{* * *} \mathrm{p}<0.01,{ }^{* *} \mathrm{p}<0.05,{ }^{*} \mathrm{p}<0.1$. 
Table 3: Dynamic Returns to Elite University Graduation

\begin{tabular}{|c|c|c|c|c|c|c|c|c|}
\hline & 1 & 2 & 3 & 4 & 5 & 6 & 7 & 8 \\
\hline & \multirow[t]{2}{*}{ All } & \multirow[t]{2}{*}{$\begin{array}{c}\text { Pre- } \\
\text { expansion }\end{array}$} & \multirow[t]{2}{*}{$\begin{array}{c}\text { Post- } \\
\text { expansion }\end{array}$} & \multirow[t]{2}{*}{ All } & \multirow[t]{2}{*}{$\begin{array}{c}\text { Pre- } \\
\text { expansion }\end{array}$} & \multirow[t]{2}{*}{$\begin{array}{c}\text { Post- } \\
\text { expansion }\end{array}$} & $\begin{array}{c}\text { Pre- } \\
\text { expansion }\end{array}$ & $\begin{array}{c}\text { Post- } \\
\text { expansion }\end{array}$ \\
\hline & & & & & & & \multicolumn{2}{|c|}{ (stable employees) } \\
\hline \multirow[t]{2}{*}{ Elite } & $0.331^{* *}$ & $0.440 * *$ & $0.352 * * *$ & $0.308^{* * *}$ & 0.246 & $0.372 * * *$ & 0.338* & $0.409 * * *$ \\
\hline & [0.161] & {$[0.222]$} & {$[0.074]$} & {$[0.118]$} & [0.212] & {$[0.079]$} & [0.189] & {$[0.071]$} \\
\hline \multirow[t]{2}{*}{ Elite x PE } & -0.026 & -0.020 & $-0.083^{* * *}$ & $-0.031 * *$ & -0.025 & $-0.086^{* * *}$ & -0.022 & $-0.087 * * *$ \\
\hline & {$[0.018]$} & [0.018] & {$[0.030]$} & [0.013] & [0.018] & [0.030] & [0.016] & [0.029] \\
\hline \multirow[t]{2}{*}{ Elite $\mathrm{x} P E^{2}$} & 0.001 & 0.000 & $0.007 * *$ & $0.001 * *$ & $0.001 * *$ & $0.007 * *$ & $0.001^{*}$ & $0.007 * *$ \\
\hline & [0.001] & {$[0.000]$} & [0.003] & {$[0.000]$} & {$[0.000]$} & [0.003] & {$[0.000]$} & [0.003] \\
\hline \multirow[t]{2}{*}{$\mathrm{PE}$} & $0.118^{* * *}$ & $0.158^{* * *}$ & $0.115^{* * *}$ & $0.048^{* * *}$ & 0.012 & $0.068 * * *$ & $0.035^{*}$ & $0.058^{* * *}$ \\
\hline & {$[0.009]$} & [0.011] & {$[0.019]$} & {$[0.008]$} & [0.021] & [0.014] & {$[0.020]$} & [0.017] \\
\hline \multirow[t]{2}{*}{$\mathrm{PE}^{2}$} & $-0.002 * * *$ & $-0.003 * * *$ & $-0.004^{* * *}$ & $-0.001 * * *$ & -0.000 & $-0.003 * *$ & -0.001 & -0.001 \\
\hline & {$[0.000]$} & {$[0.000]$} & {$[0.002]$} & {$[0.000]$} & {$[0.000]$} & [0.001] & {$[0.000]$} & [0.001] \\
\hline \multirow[t]{2}{*}{ Male } & 0.050 & $0.167 * * *$ & $0.118^{* *}$ & $0.158 * * *$ & $0.213^{* * *}$ & $0.137 * * *$ & $0.165^{* * *}$ & $0.103^{*}$ \\
\hline & [0.041] & {$[0.047]$} & {$[0.048]$} & {$[0.033]$} & {$[0.032]$} & {$[0.046]$} & [0.033] & [0.057] \\
\hline \multirow{2}{*}{$\hat{E}_{r t}^{C O L}$} & & & & $0.027 * * *$ & $0.039 * * *$ & $0.015 * * *$ & $0.034 * * *$ & $0.017 * * *$ \\
\hline & & & & {$[0.002]$} & {$[0.004]$} & [0.004] & [0.004] & [0.005] \\
\hline \multirow[t]{2}{*}{ Constant } & $7.315^{* * *}$ & $6.607 * * *$ & $7.603^{* * *}$ & $6.205^{* * *}$ & $5.970 * * *$ & $6.848 * * *$ & $5.987 * * *$ & $6.773^{* * *}$ \\
\hline & {$[0.058]$} & {$[0.073]$} & [0.059] & [0.061] & {$[0.057]$} & {$[0.256]$} & {$[0.076]$} & {$[0.267]$} \\
\hline City fixed effects & Yes & Yes & Yes & Yes & Yes & Yes & Yes & Yes \\
\hline $\begin{array}{l}\text { Excluding firm } \\
\text { changers }\end{array}$ & No & No & No & No & No & No & Yes & Yes \\
\hline Observations & 2,839 & 1,369 & 1,470 & 2,839 & 1,369 & 1,470 & 949 & 1,155 \\
\hline $\begin{array}{l}\text { Number of } \\
\text { individuals }\end{array}$ & 1,470 & 717 & 753 & 1,470 & 717 & 753 & 503 & 590 \\
\hline
\end{tabular}

Notes: The panel data sample includes all full-time workers with hourly wage between 1 and 100 Yuan per hour and a four-year college degree, aged 20 to 60 . The post-expansion cohort sample refers to individuals born in or after 1980; the pre-expansion cohort sample individuals born between 1953 and 1979. Dependent variable is the natural logarithm of monthly CPI-adjusted wage, measured in 2013 and in the year when one starts the current job. Explanatory variables include a dummy variable indicating elite university graduates (Elite), potential experience ( $\mathrm{PE}=$ Age-years of schooling-6) and its square $\left(\mathrm{PE}^{2}\right)$, interaction terms between Elite and potential experience ( $\mathrm{PE}$ and $\mathrm{PE}^{2}$ ), a dummy for male workers, time-varying province-specific demand for college graduates ( $\hat{E}_{r t}^{C O L}$, as a percentage of total labor demand), and city fixed effects. Columns 7 and 8 replicate columns 5 and 6 for the sample of individuals who have never changed firms. Robust standard errors clustered at province level are in brackets. Significance levels: ${ }^{* * *} \mathrm{p}<0.01,{ }^{* *} \mathrm{p}<0.05,{ }^{*} \mathrm{p}<0.1$. 
Table 4: Dynamic Returns to Elite University Graduation Adjusted for University Selectivity (post-expansion cohort)

\begin{tabular}{|c|c|c|c|c|}
\hline & 1 & 2 & 3 & 4 \\
\hline \multirow[t]{2}{*}{ Elite } & $0.306^{* * *}$ & $0.361 * * *$ & $0.285^{* * *}$ & $0.346^{* * *}$ \\
\hline & {$[0.094]$} & {$[0.079]$} & {$[0.103]$} & [0.085] \\
\hline \multirow[t]{2}{*}{ Elite x PE } & $-0.105^{* * *}$ & $-0.108 * * *$ & $-0.097^{* *}$ & $-0.106^{* * *}$ \\
\hline & {$[0.036]$} & {$[0.029]$} & {$[0.038]$} & {$[0.028]$} \\
\hline \multirow[t]{2}{*}{ Elite $x \mathrm{PE}^{2}$} & $0.008^{* *}$ & $0.008^{* * *}$ & $0.008^{* *}$ & $0.008^{* * *}$ \\
\hline & {$[0.003]$} & [0.003] & {$[0.003]$} & {$[0.003]$} \\
\hline \multirow[t]{2}{*}{ Gaokao z-score } & $0.163 * * *$ & $0.169 * * *$ & $0.191 * * *$ & $0.185^{* * *}$ \\
\hline & {$[0.055]$} & {$[0.057]$} & {$[0.058]$} & {$[0.063]$} \\
\hline \multirow[t]{2}{*}{ Gaokao z-score x PE } & & & -0.008 & 0.005 \\
\hline & & & {$[0.019]$} & {$[0.025]$} \\
\hline \multirow[t]{2}{*}{ Gaokao z-score x PE² } & & & 0.000 & -0.001 \\
\hline & & & {$[0.002]$} & {$[0.003]$} \\
\hline \multirow[t]{2}{*}{ PE } & $0.066^{* * *}$ & $0.069 * * *$ & $0.068 * * *$ & $0.066^{* * *}$ \\
\hline & {$[0.014]$} & {$[0.016]$} & [0.014] & [0.018] \\
\hline \multirow[t]{2}{*}{$\mathrm{PE}^{2}$} & $-0.002 *$ & -0.002 & -0.002 & -0.001 \\
\hline & {$[0.001]$} & {$[0.001]$} & {$[0.001]$} & {$[0.002]$} \\
\hline \multirow[t]{2}{*}{ Male } & $0.150 * * *$ & $0.107 *$ & $0.151^{* * *}$ & $0.109 *$ \\
\hline & {$[0.050]$} & {$[0.063]$} & {$[0.051]$} & {$[0.064]$} \\
\hline \multirow{2}{*}{$\hat{E}_{r t}^{C O L}$} & $0.014 * * *$ & $0.014 * * *$ & $0.014^{* * *}$ & $0.014 * * *$ \\
\hline & {$[0.005]$} & {$[0.005]$} & {$[0.005]$} & {$[0.005]$} \\
\hline \multirow[t]{2}{*}{ Constant } & $6.889 * * *$ & $6.840 * * *$ & $6.883 * * *$ & $6.835^{* * *}$ \\
\hline & {$[0.279]$} & {$[0.288]$} & {$[0.276]$} & {$[0.287]$} \\
\hline City fixed effects & Yes & Yes & Yes & Yes \\
\hline $\begin{array}{l}\text { Excluding firm } \\
\text { changers }\end{array}$ & No & Yes & No & Yes \\
\hline Observations & 1,199 & 939 & 1,199 & 939 \\
\hline Number of individuals & 610 & 476 & 610 & 476 \\
\hline
\end{tabular}

Notes: The panel data sample includes all full-time workers with hourly wage between 1 and 100 Yuan per hour and a four-year college degree, born in or after 1980 (post-expansion cohort sample). Dependent variable is the natural logarithm of monthly CPI-adjusted wage, measured in 2013 and in the year when one starts the current job. Explanatory variables include a dummy variable indicating elite university graduates (Elite), potential experience ( $P E=$ Age-years of schooling-6) and its square $\left(P E^{2}\right)$, interaction terms between Elite and potential experience ( $P E$ and $P E^{2}$ ), the Gaokao z-score (normalized first by the maximum possible score of the test one took, and then to a z-score with mean zero and standard deviation of one) and its interaction with $P E$ and $P E^{2}$, a dummy for male workers, time-varying province-specific demand for college graduates ( $\hat{E}_{r t}^{C O L}$, as a percentage 
of total labor demand), and city fixed effects. Columns 2 and 4 replicate columns 1 and 3 for the sample of individuals who have never changed firms. Robust standard errors clustered at province level are in brackets. Significance levels: ${ }^{* * *} \mathrm{p}<0.01,{ }^{* *} \mathrm{p}<0.05,{ }^{*} \mathrm{p}<0.1$. 
Table 5: Dynamic Returns to Elite University Graduation within Industry, Occupation, and Sector (post-expansion cohort)

\begin{tabular}{|c|c|c|c|c|c|}
\hline & 1 & 2 & 3 & 4 & 5 \\
\hline \multirow[t]{2}{*}{ Elite } & $0.300^{* * *}$ & $0.280^{* * *}$ & $0.304^{* * * *}$ & $0.268^{* * * *}$ & $0.305^{* * * *}$ \\
\hline & {$[0.081]$} & {$[0.078]$} & {$[0.084]$} & {$[0.074]$} & {$[0.073]$} \\
\hline \multirow[t]{2}{*}{ Elite $\mathrm{x} P \mathrm{E}$} & $-0.110 * * *$ & $-0.110 * * *$ & $-0.109 * * *$ & $-0.106 * * *$ & $-0.096 * * *$ \\
\hline & {$[0.031]$} & {$[0.030]$} & {$[0.030]$} & {$[0.032]$} & [0.035] \\
\hline \multirow[t]{2}{*}{ Elite $\mathrm{x} \mathrm{PE}^{2}$} & $0.008^{* * *}$ & $0.008^{* * *}$ & $0.008^{* * *}$ & $0.008^{* * *}$ & $0.007 * *$ \\
\hline & {$[0.003]$} & {$[0.003]$} & {$[0.003]$} & {$[0.003]$} & {$[0.003]$} \\
\hline \multirow[t]{2}{*}{ Gaokao z-score } & $0.163^{* * *}$ & $0.155^{* * *}$ & $0.169 * * *$ & $0.160^{* * *}$ & $0.177 * * *$ \\
\hline & {$[0.057]$} & {$[0.057]$} & {$[0.061]$} & {$[0.058]$} & {$[0.058]$} \\
\hline \multirow[t]{2}{*}{ PE } & $0.064 * * *$ & $0.067 * * *$ & $0.063^{* * *}$ & $0.065^{* * *}$ & $0.064^{* * *}$ \\
\hline & {$[0.015]$} & [0.014] & [0.014] & [0.014] & [0.021] \\
\hline \multirow[t]{2}{*}{$\mathrm{PE}^{2}$} & -0.002 & -0.002 & -0.001 & -0.002 & -0.001 \\
\hline & {$[0.001]$} & {$[0.001]$} & {$[0.001]$} & {$[0.001]$} & {$[0.002]$} \\
\hline \multirow[t]{2}{*}{ Male } & $0.141^{* * *}$ & $0.149 * * *$ & $0.134^{* * *}$ & $0.141^{* *}$ & $0.116^{*}$ \\
\hline & {$[0.054]$} & {$[0.056]$} & {$[0.050]$} & {$[0.056]$} & {$[0.062]$} \\
\hline \multirow[t]{2}{*}{$\hat{E}_{r t}^{C O L}$} & $0.014 * * *$ & $0.013^{* * *}$ & $0.013 * * *$ & $0.013^{* * *}$ & $0.013^{* * *}$ \\
\hline & {$[0.005]$} & {$[0.004]$} & {$[0.005]$} & {$[0.004]$} & {$[0.004]$} \\
\hline \multirow[t]{2}{*}{ Constant } & $7.173^{* * *}$ & $6.823^{* * *}$ & $6.910 * * *$ & $7.089 * * *$ & $7.433^{* * *}$ \\
\hline & [0.423] & {$[0.327]$} & [0.312] & [0.434] & {$[0.296]$} \\
\hline City fixed effects & Yes & Yes & Yes & Yes & Yes \\
\hline Industry fixed effects & Yes & No & No & Yes & Yes \\
\hline Occupation fixed effects & No & Yes & No & Yes & Yes \\
\hline Sector fixed effects & No & No & Yes & Yes & Yes \\
\hline Excluding firm changers & No & No & No & No & Yes \\
\hline Observations & 1,173 & 1,173 & 1,173 & 1,173 & 925 \\
\hline Number of individuals & 595 & 595 & 595 & 595 & 468 \\
\hline
\end{tabular}

Notes: The panel data sample includes all full-time workers with hourly wage between 1 and 100 Yuan per hour and a four-year college degree, born in or after 1980. Model specifications are the same as that in column 1 of Table 4 except with industry, occupation, and sector fixed effects added separately in columns 1-3 and jointly in column 4. Column 5 replicates column 2 in Table 4 for the sample of individuals who have never changed firms. Robust standard errors clustered at province level are in brackets. Significance levels: ${ }^{* * *} \mathrm{p}<0.01, * *$ $\mathrm{p}<0.05, * \mathrm{p}<0.1$. 
Table 6: Dynamic Returns to Elite University Graduation with Alternative Controls for Labor Market Factors (post-expansion cohort)

\begin{tabular}{|c|c|c|c|c|c|c|c|c|}
\hline & $\begin{array}{c}1 \\
\text { Bachelor's } \\
\text { degree } \\
\text { only }\end{array}$ & $\begin{array}{c}2 \\
\text { Master's } \\
\text { degree or } \\
\text { above }\end{array}$ & $\begin{array}{c}3 \\
\text { >national } \\
\text { college } \\
\text { exp level }\end{array}$ & \begin{tabular}{l}
\multicolumn{1}{c}{4} \\
<national \\
college \\
exp level
\end{tabular} & $\begin{array}{c}5 \\
\text { >med HC } \\
\text { intensity } \\
\text { ind VA \% }\end{array}$ & $\begin{array}{c}6 \\
<\text { med HC } \\
\text { intensity } \\
\text { id VA \% }\end{array}$ & $\begin{array}{c}7 \\
\text { City- } \\
\text { specific } \\
\text { time trend }\end{array}$ & $\begin{array}{c}8 \\
\text { Individual } \\
\text { FEs }\end{array}$ \\
\hline Elite & $\begin{array}{c}0.348^{* * *} \\
{[0.093]}\end{array}$ & $\begin{array}{c}0.044 \\
{[0.196]}\end{array}$ & $\begin{array}{c}0.471^{* * *} \\
{[0.150]}\end{array}$ & $\begin{array}{c}0.156 \\
{[0.132]}\end{array}$ & $\begin{array}{c}0.334 * * * \\
{[0.079]}\end{array}$ & $\begin{array}{c}0.219 \\
{[0.263]}\end{array}$ & $\begin{array}{c}0.376^{* * *} \\
{[0.117]}\end{array}$ & \\
\hline Elite x PE & $\begin{array}{c}-0.147 * * * \\
{[0.037]}\end{array}$ & $\begin{array}{c}-0.073 \\
{[0.059]}\end{array}$ & $\begin{array}{c}-0.182 * * * \\
{[0.064]}\end{array}$ & $\begin{array}{l}-0.050 \\
{[0.059]}\end{array}$ & $\begin{array}{c}-0.114 * * * \\
{[0.032]}\end{array}$ & $\begin{array}{c}-0.085 \\
{[0.106]}\end{array}$ & $\begin{array}{c}-0.133^{* * *} \\
{[0.042]}\end{array}$ & $\begin{array}{c}-0.100^{* *} \\
{[0.043]}\end{array}$ \\
\hline Elite $x \mathrm{PE}^{2}$ & $\begin{array}{c}0.012 * * * \\
{[0.004]}\end{array}$ & $\begin{array}{l}0.011^{* *} \\
{[0.005]}\end{array}$ & $\begin{array}{c}0.014^{* *} \\
{[0.006]}\end{array}$ & $\begin{array}{c}0.004 \\
{[0.006]}\end{array}$ & $\begin{array}{c}0.009 * * * \\
{[0.003]}\end{array}$ & $\begin{array}{c}0.005 \\
{[0.009]}\end{array}$ & $\begin{array}{c}0.010 * * * \\
{[0.004]}\end{array}$ & $\begin{array}{c}0.008^{* *} \\
{[0.003]}\end{array}$ \\
\hline Gaokao z-score & $\begin{array}{l}0.083^{*} \\
{[0.042]}\end{array}$ & $\begin{array}{c}0.159 \\
{[0.156]}\end{array}$ & $\begin{array}{c}0.133^{* *} \\
{[0.067]}\end{array}$ & $\begin{array}{c}0.207 * * * \\
{[0.058]}\end{array}$ & $\begin{array}{c}0.181^{* * *} \\
{[0.059]}\end{array}$ & $\begin{array}{c}0.118 \\
{[0.099]}\end{array}$ & $\begin{array}{c}0.155^{* *} \\
{[0.060]}\end{array}$ & \\
\hline PE & $\begin{array}{c}0.073 * * * \\
{[0.014]}\end{array}$ & $\begin{array}{c}0.057 \\
{[0.043]}\end{array}$ & $\begin{array}{c}0.097 * * * \\
{[0.018]}\end{array}$ & $\begin{array}{c}0.033 \\
{[0.025]}\end{array}$ & $\begin{array}{c}0.090 * * * \\
{[0.014]}\end{array}$ & $\begin{array}{c}0.017 \\
{[0.030]}\end{array}$ & $\begin{array}{c}0.083 * * * \\
{[0.013]}\end{array}$ & $\begin{array}{c}0.019 \\
{[0.044]}\end{array}$ \\
\hline $\mathrm{PE}^{2}$ & $\begin{array}{l}-0.002 * \\
{[0.001]}\end{array}$ & $\begin{array}{c}-0.006 \\
{[0.005]}\end{array}$ & $\begin{array}{c}-0.005^{* *} \\
{[0.002]}\end{array}$ & $\begin{array}{c}0.000 \\
{[0.002]}\end{array}$ & $\begin{array}{c}-0.003^{* *} \\
{[0.001]}\end{array}$ & $\begin{array}{c}0.000 \\
{[0.002]}\end{array}$ & $\begin{array}{c}-0.004 * * * \\
{[0.001]}\end{array}$ & $\begin{array}{c}-0.002 \\
{[0.001]}\end{array}$ \\
\hline Male & $\begin{array}{c}0.166^{* * *} \\
{[0.053]}\end{array}$ & $\begin{array}{c}0.200^{* * *} \\
{[0.058]}\end{array}$ & $\begin{array}{c}0.189 * * \\
{[0.080]}\end{array}$ & $\begin{array}{c}0.120^{* *} \\
{[0.055]}\end{array}$ & $\begin{array}{l}0.089 * \\
{[0.047]}\end{array}$ & $\begin{array}{c}0.242 * * * \\
{[0.088]}\end{array}$ & $\begin{array}{c}0.147 * * * \\
{[0.052]}\end{array}$ & \\
\hline$\hat{E}_{r t}^{C O L}$ & $\begin{array}{l}0.011^{* *} \\
\quad[0.004]\end{array}$ & $\begin{array}{c}0.030 * * * \\
{[0.005]}\end{array}$ & $\begin{array}{c}0.015 \\
{[0.010]}\end{array}$ & $\begin{array}{c}0.017^{* * *} \\
{[0.004]}\end{array}$ & $\begin{array}{l}0.011^{*} \\
{[0.006]}\end{array}$ & $\begin{array}{c}0.022 * * \\
{[0.009]}\end{array}$ & $\begin{array}{c}-0.035^{* *} \\
{[0.018]}\end{array}$ & $\begin{array}{l}0.030^{*} \\
{[0.015]}\end{array}$ \\
\hline Constant & $\begin{array}{c}6.959 * * * \\
{[0.253]}\end{array}$ & $\begin{array}{c}6.356 * * * \\
{[0.333]}\end{array}$ & $\begin{array}{c}6.975^{* * *} \\
{[0.456]}\end{array}$ & $\begin{array}{c}6.736^{* * *} \\
{[0.287]}\end{array}$ & $\begin{array}{c}7.003 * * * \\
{[0.348]}\end{array}$ & $\begin{array}{c}5.776 * * * \\
{[0.742]}\end{array}$ & $\begin{array}{c}0.738 \\
{[1.765]}\end{array}$ & $\begin{array}{c}6.093^{* * *} \\
{[0.700]}\end{array}$ \\
\hline City fixed effects & Yes & Yes & Yes & Yes & Yes & Yes & Yes & Yes \\
\hline $\begin{array}{l}\text { Observations } \\
\text { Number of } \\
\text { individuals }\end{array}$ & 1,088 & 111 & 581 & 618 & 759 & 440 & 1,199 & 1,199 \\
\hline
\end{tabular}

Notes: The panel data sample includes all full-time workers with hourly wage between 1 and 100 Yuan per hour and a four-year college degree, born in or after 1980. Columns 1 and 2 use samples of individuals with bachelor's degree only and master's degree or above respectively. Columns 3 and 4 use samples of provinces where the college admissions growth is above and below the national average respective. Columns 5 and 6 use samples of provinces where the human capital-intensity of industries (measure by the weighted sum of nationwide share of college-educated employees by industry weighted by industrial value-added share in province GDP) are above and below the national median respectively. Columns 7 uses the full sample and controls for city-specific time trend. Column 8 uses the full sample and control individual fixed effects. Model specifications in columns 1-6 are the same as that in column 1 of Table 4 . Robust standard errors clustered at province level are in brackets. Significance levels: ${ }^{* *} \mathrm{p}<0.01,{ }^{* *} \mathrm{p}<0.05,{ }^{*} \mathrm{p}<0.1$. 
Table 7: Dynamic Returns to Elite University Graduation by Regional Economic Characteristics (post-expansion cohort)

\begin{tabular}{|c|c|c|c|c|c|c|}
\hline & $\begin{array}{c}1 \\
\text { coastal }\end{array}$ & $\begin{array}{c}2 \\
\text { inland }\end{array}$ & $\begin{array}{c}3 \\
\geq \text { median } \\
\text { service } \\
\text { share }\end{array}$ & $\begin{array}{c}4 \\
<\text { median } \\
\text { service } \\
\text { share }\end{array}$ & $\begin{array}{c}5 \\
\geq \text { median } \\
\text { agriculture } \\
\text { share }\end{array}$ & $\begin{array}{c}6 \\
\text { <median } \\
\text { agriculture } \\
\text { share }\end{array}$ \\
\hline Elite & $\begin{array}{c}0.384 * * * \\
{[0.044]}\end{array}$ & $\begin{array}{c}0.195 \\
{[0.186]}\end{array}$ & $\begin{array}{c}0.367 * * * \\
{[0.086]}\end{array}$ & $\begin{array}{c}0.149 \\
{[0.139]}\end{array}$ & $\begin{array}{c}0.248 \\
{[0.193]}\end{array}$ & $\begin{array}{c}0.360 * * * \\
{[0.085]}\end{array}$ \\
\hline Elite $\mathrm{x}$ PE & $\begin{array}{c}-0.144 * * * \\
{[0.032]}\end{array}$ & $\begin{array}{c}-0.046 \\
{[0.070]}\end{array}$ & $\begin{array}{c}-0.137 * * * \\
{[0.043]}\end{array}$ & $\begin{array}{c}-0.051 \\
{[0.076]}\end{array}$ & $\begin{array}{c}-0.022 \\
{[0.063]}\end{array}$ & $\begin{array}{c}-0.172^{* * *} \\
{[0.046]}\end{array}$ \\
\hline Elite $\mathrm{x} \mathrm{PE}^{2}$ & $\begin{array}{c}0.012^{* * *} \\
{[0.003]}\end{array}$ & $\begin{array}{c}0.002 \\
{[0.006]}\end{array}$ & $\begin{array}{c}0.009 * * \\
{[0.004]}\end{array}$ & $\begin{array}{c}0.006 \\
{[0.006]}\end{array}$ & $\begin{array}{c}0.001 \\
{[0.005]}\end{array}$ & $\begin{array}{c}0.014 * * * \\
{[0.004]}\end{array}$ \\
\hline Gaokao z-score & $\begin{array}{c}0.200 * * * \\
{[0.060]}\end{array}$ & $\begin{array}{c}0.125^{* *} \\
{[0.056]}\end{array}$ & $\begin{array}{c}0.252 * * * \\
{[0.044]}\end{array}$ & $\begin{array}{c}0.048 \\
{[0.055]}\end{array}$ & $\begin{array}{c}0.041 \\
{[0.059]}\end{array}$ & $\begin{array}{c}0.238 * * * \\
{[0.041]}\end{array}$ \\
\hline PE & $\begin{array}{c}0.082 * * * \\
{[0.008]}\end{array}$ & $\begin{array}{c}0.054^{* *} \\
{[0.021]}\end{array}$ & $\begin{array}{c}0.076^{* * *} \\
{[0.017]}\end{array}$ & $\begin{array}{c}0.058 * * \\
{[0.027]}\end{array}$ & $\begin{array}{c}0.028 \\
{[0.026]}\end{array}$ & $\begin{array}{c}0.105^{* * *} \\
{[0.020]}\end{array}$ \\
\hline $\mathrm{PE}^{2}$ & $\begin{array}{c}-0.002 \\
{[0.002]}\end{array}$ & $\begin{array}{c}-0.001 \\
{[0.001]}\end{array}$ & $\begin{array}{c}-0.002 \\
{[0.002]}\end{array}$ & $\begin{array}{c}-0.001 \\
{[0.002]}\end{array}$ & $\begin{array}{c}0.001 \\
{[0.002]}\end{array}$ & $\begin{array}{c}-0.005^{* * *} \\
{[0.002]}\end{array}$ \\
\hline Male & $\begin{array}{c}-0.002 \\
{[0.061]}\end{array}$ & $\begin{array}{c}0.270 * * * \\
{[0.039]}\end{array}$ & $\begin{array}{c}0.102^{* *} \\
{[0.041]}\end{array}$ & $\begin{array}{c}0.203^{* *} \\
{[0.094]}\end{array}$ & $\begin{array}{c}0.167 * * \\
{[0.066]}\end{array}$ & $\begin{array}{c}0.142 * * \\
{[0.065]}\end{array}$ \\
\hline$\hat{E}_{r t}^{C O L}$ & $\begin{array}{c}0.014^{* *} \\
{[0.006]}\end{array}$ & $\begin{array}{l}0.012 * \\
{[0.007]}\end{array}$ & $\begin{array}{c}0.016^{* * *} \\
{[0.005]}\end{array}$ & $\begin{array}{c}0.010 \\
{[0.006]}\end{array}$ & $\begin{array}{c}0.013^{* *} \\
{[0.006]}\end{array}$ & $\begin{array}{c}0.015^{* * *} \\
{[0.006]}\end{array}$ \\
\hline Constant & $\begin{array}{c}6.829 * * * \\
{[0.373]}\end{array}$ & $\begin{array}{c}6.692 * * * \\
{[0.584]}\end{array}$ & $\begin{array}{c}6.708 * * * \\
{[0.298]}\end{array}$ & $\begin{array}{c}6.712 * * * \\
{[0.235]}\end{array}$ & $\begin{array}{c}6.431 * * * \\
{[0.481]}\end{array}$ & $\begin{array}{c}6.700^{* * *} \\
{[0.321]}\end{array}$ \\
\hline City fixed effects & Yes & Yes & Yes & Yes & Yes & Yes \\
\hline Observations & 522 & 677 & 612 & 587 & 638 & 561 \\
\hline Number of individuals & 262 & 348 & 311 & 299 & 325 & 285 \\
\hline
\end{tabular}

Notes: The panel data sample includes all full-time workers with hourly wage between 1 and 100 Yuan per hour and a four-year college degree, born in or after 1980. Each column is a separate regression estimated on different samples. Columns 1 and 2 are samples of individuals from respectively, coastal provinces (Beijing, Jiangsu, Shandong, Guangdong) and inland provinces (Shanxi, Liaoning, Anhui, Henan, Hubei, Hunan, Chongqing, Sichuan, Yunnan, Gansu); columns 3 and 4 are samples of cities where the share of GDP from the service sector is above or below the national median in 2011; columns 5 and 6 are samples of cities where the share of GDP from the agricultural sector is above or below the national median in 2011. Model specifications are the same as that in column 1 of Table 4 . Robust standard errors clustered at province level are in brackets. Significance levels: *** $\mathrm{p}<0.01,{ }^{* *} \mathrm{p}<0.05,{ }^{*} \mathrm{p}<0.1$. 
Table 8: Returns to Elite University Graduation by Regional Foreign Direct Investment (post-expansion cohort)

\begin{tabular}{|c|c|c|c|c|}
\hline & $\begin{array}{c}1 \\
\geq \text { median } \\
\text { FDI VA \% }\end{array}$ & $\begin{array}{c}2 \\
<\text { median } \\
\text { FDI VA \% }\end{array}$ & $\begin{array}{c}3 \\
\geq \text { median } \\
\text { FDI number \% }\end{array}$ & $\begin{array}{c}4 \\
<\text { median } \\
\text { FDI number \% }\end{array}$ \\
\hline Elite & $\begin{array}{c}0.259 * * \\
{[0.106]}\end{array}$ & $\begin{array}{c}0.371^{* *} \\
{[0.164]}\end{array}$ & $\begin{array}{c}0.354 * * * \\
{[0.062]}\end{array}$ & $\begin{array}{c}0.219 \\
{[0.207]}\end{array}$ \\
\hline Elite $\mathrm{x} P E$ & $\begin{array}{c}-0.113^{* * *} \\
{[0.042]}\end{array}$ & $\begin{array}{c}-0.107^{*} \\
{[0.059]}\end{array}$ & $\begin{array}{c}-0.136^{* * *} \\
{[0.033]}\end{array}$ & $\begin{array}{l}-0.070 \\
{[0.071]}\end{array}$ \\
\hline Elite $\mathrm{x} \mathrm{PE}^{2}$ & $\begin{array}{l}0.008^{*} \\
{[0.004]}\end{array}$ & $\begin{array}{l}0.009 * \\
{[0.005]}\end{array}$ & $\begin{array}{c}0.010^{* * *} \\
{[0.003]}\end{array}$ & $\begin{array}{c}0.005 \\
{[0.006]}\end{array}$ \\
\hline Gaokao z-score & $\begin{array}{c}0.259 * * * \\
{[0.043]}\end{array}$ & $\begin{array}{c}0.013 \\
{[0.042]}\end{array}$ & $\begin{array}{c}0.232 * * * \\
{[0.043]}\end{array}$ & $\begin{array}{c}0.048 \\
{[0.061]}\end{array}$ \\
\hline $\mathrm{PE}$ & $\begin{array}{c}0.069 * * * \\
{[0.015]}\end{array}$ & $\begin{array}{l}0.065^{* *} \\
{[0.029]}\end{array}$ & $\begin{array}{c}0.081^{* * *} \\
{[0.010]}\end{array}$ & $\begin{array}{l}0.053^{* *} \\
{[0.025]}\end{array}$ \\
\hline $\mathrm{PE}^{2}$ & $\begin{array}{l}-0.002 \\
{[0.002]}\end{array}$ & $\begin{array}{l}-0.002 \\
{[0.002]}\end{array}$ & $\begin{array}{l}-0.002 \\
{[0.002]}\end{array}$ & $\begin{array}{l}-0.002 \\
{[0.002]}\end{array}$ \\
\hline Male & $\begin{array}{l}0.080^{*} \\
{[0.044]}\end{array}$ & $\begin{array}{c}0.235^{* * *} \\
{[0.071]}\end{array}$ & $\begin{array}{c}0.053 \\
{[0.051]}\end{array}$ & $\begin{array}{c}0.267^{* * *} \\
{[0.052]}\end{array}$ \\
\hline$\hat{E}_{r t}^{C O L}$ & $\begin{array}{c}0.016^{* * *} \\
{[0.005]}\end{array}$ & $\begin{array}{c}0.010 \\
{[0.006]}\end{array}$ & $\begin{array}{c}0.015^{* * *} \\
{[0.006]}\end{array}$ & $\begin{array}{l}0.011 * \\
{[0.006]}\end{array}$ \\
\hline Constant & $\begin{array}{c}6.749 * * * \\
{[0.330]}\end{array}$ & $\begin{array}{c}6.699 * * * \\
{[0.208]}\end{array}$ & $\begin{array}{c}6.739 * * * \\
{[0.346]}\end{array}$ & $\begin{array}{c}6.652^{* * *} \\
{[0.198]}\end{array}$ \\
\hline City fixed effects & Yes & Yes & Yes & Yes \\
\hline Observations & 602 & 597 & 601 & 598 \\
\hline Number of individuals & 305 & 305 & 304 & 306 \\
\hline
\end{tabular}

Notes: The panel data sample includes all full-time workers with hourly wage between 1 and 100 Yuan per hour and a four-year college degree, born in or after 1980. Each column is a separate regression estimated on different samples. Columns 1 and 2 are samples of cities whose value-added share from foreign-owned firms (FDI) is above or below the national median in 2011, and columns 3 and 4 are samples of cities where the fraction of foreign-owned firms is above or below the national median in 2011. Model specifications are the same as that in column 1 of Table 4 . Robust standard errors clustered at province level in brackets.

Significance levels: ${ }^{* * *} \mathrm{p}<0.01,{ }^{* *} \mathrm{p}<0.05,{ }^{*} \mathrm{p}<0.1$. 
Table 9: Returns to Elite University Graduation by Job Sector (post-expansion cohort)

\begin{tabular}{|c|c|c|c|}
\hline & $\begin{array}{c}1 \\
\text { Government agencies+ } \\
\text { public institutions }\end{array}$ & $\begin{array}{c}2 \\
\text { private + SOE }\end{array}$ & private firms \\
\hline \multirow[t]{2}{*}{ Elite } & 0.221 & $0.313^{* * *}$ & $0.378^{* *}$ \\
\hline & {$[0.182]$} & {$[0.102]$} & {$[0.148]$} \\
\hline \multirow[t]{2}{*}{ Elite $x$ PE } & -0.083 & $-0.123 * * *$ & $-0.163 * * *$ \\
\hline & [0.069] & {$[0.037]$} & {$[0.055]$} \\
\hline \multirow[t]{2}{*}{ Elite $\mathrm{x} \mathrm{PE}^{2}$} & 0.005 & $0.011^{* * *}$ & $0.013^{* *}$ \\
\hline & {$[0.005]$} & {$[0.004]$} & {$[0.006]$} \\
\hline \multirow[t]{2}{*}{ Gaokao z-score } & 0.161 & $0.216 * * *$ & $0.221^{* * *}$ \\
\hline & [0.101] & {$[0.066]$} & {$[0.071]$} \\
\hline \multirow[t]{2}{*}{ PE } & $0.070^{*}$ & $0.065^{* * *}$ & $0.064 * * *$ \\
\hline & {$[0.038]$} & {$[0.017]$} & {$[0.022]$} \\
\hline \multirow[t]{2}{*}{$\mathrm{PE}^{2}$} & -0.002 & $-0.002 *$ & -0.001 \\
\hline & {$[0.003]$} & {$[0.001]$} & {$[0.002]$} \\
\hline \multirow[t]{2}{*}{ Male } & 0.074 & $0.176^{* * *}$ & $0.160^{* *}$ \\
\hline & {$[0.061]$} & {$[0.055]$} & {$[0.074]$} \\
\hline \multirow{2}{*}{$\hat{E}_{r t}^{C O L}$} & $0.019 * * *$ & $0.009 * *$ & 0.007 \\
\hline & {$[0.007]$} & {$[0.004]$} & {$[0.006]$} \\
\hline \multirow[t]{2}{*}{ Constant } & $6.587 * * *$ & $7.152 * * *$ & $7.350 * * *$ \\
\hline & {$[0.416]$} & {$[0.237]$} & {$[0.360]$} \\
\hline City fixed effects & Yes & Yes & Yes \\
\hline Observations & 496 & 703 & 427 \\
\hline Number of individuals & 253 & 357 & 217 \\
\hline
\end{tabular}

Notes: The panel data sample includes all full-time workers with hourly wage between 1 and 100 Yuan per hour and a four-year college degree, born in or after 1980. Column 1 is estimated from the sample of individuals working in the public sector, i.e., government agencies and public institutions; column 2 employs the sample of individuals working in the private sector (domestic private firms and foreign owned firms) and state-owned enterprises (SOEs); and column 3 employs the sample of individuals working in the private sector. Model specifications are the same as that in column 1 of Table 4 . Robust standard errors clustered at province level in brackets. Significance levels: ${ }^{* * *} \mathrm{p}<0.01,{ }^{* *} \mathrm{p}<0.05,{ }^{*} \mathrm{p}<0.1$. 